\title{
THE CHEMICAL BREAKAGE OF CHROMOSOMES
}

\author{
By C. D. DARLINGTON \\ John Innes Horticultural Institution, Merton \\ and \\ P. C. KOLLER \\ Chester Beatty Research Institute \\ Royal Cancer Hospital, Fulham Road, London
}

\section{CONTENTS}

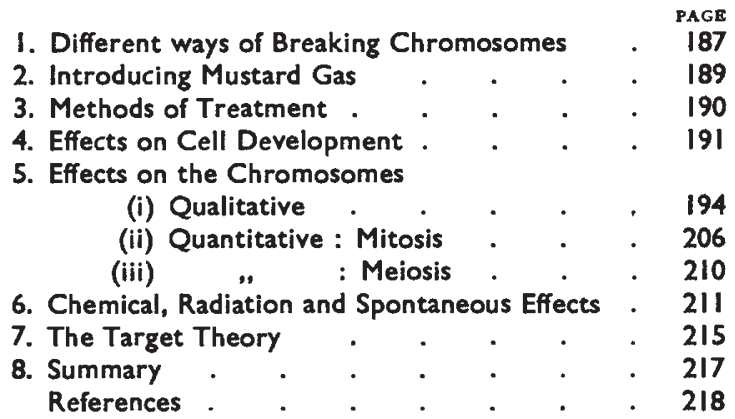

\section{(I) DIFFERENT WAYS OF BREAKING CHROMOSOMES}

InJuRIEs to chromosomes and genes fall into two classes which we describe as spontaneous and induced. The spontaneous effects are due to errors or abnormalities in the reaction of the genotype to the environment. They probably cover the whole gamut of possibilities. At one extreme no environment will remedy the mutafacient effect of the abnormal genotype. Here we have Beadle's "sticky" maize. At the other extreme no genotype will remedy the effect of the abnormal environment. Here we have sister-reunion of chromatids due to non-division of the end-gene, a regular property of aged pollen. Since temperature is the chief environmental variable concerned, and since low temperature will produce by nucleic acid starvation the same sister-reunion, we see that the distinction between spontaneous errors and induced ones is purely a matter of the exactness of our control which is continually increasing.

An important section of effects could never be described as spontaneous. They arise by three agencies :--

(i) Ionising radiations, such as $\mathrm{X}$-rays, $\alpha$ and $\beta$ particles and neutrons (Lea, 1946).

(ii) Molecular excitation with ultra-violet light (Stadler, I94I ; Mackenzie and Muller, I940 ; Hollaender, 1946). $\times 87$ 
(iii) Chemical treatments: the substances which act as nuclear mutafacients, or gene and chromosome breakers, ${ }^{*}$ are of many kinds. So far we know that the following can induce gene or chromosome mutations or both, without killing :-

Potassium thiocyanate (Stubbe, 1940).

Ethylurethane (Oehlkers, 1943).

Sulphur and nitrogen mustards (Auerbach, r943;

Koller, I943; Reports to the Ministry of Supply;

Horowitz et al., I946).

Sulphonamides (Chevais and Thomas, r943).

Allyl isothiocyanite (Auerbach and Robson, 1944).

Phenol (Hadorn and Niggli, r946).

Of these different treatments the most detailed account of the effects is that given for the action of X-rays on mitosis in plants (Darlington and La Cour, 1945). The effects may be classified in the light of recent knowledge as of three kinds ( $c f$. Darlington, I942, I947).

Centromere effects. These consist of breakage at or within the centromere of one or both chromatids. Such breakage may happen either before metaphase (when it may be followed by reunions or at least fluid nucleic acid attachments), or at anaphase under the strain of movement. Distinct from this breakage is misdivision of the centromere such as takes place spontaneously at meiosis and leads to the formation of isochromosomes by reunion of the chromatids within the centromere.

Nucleic acid effects. These are sometimes associated with fluid, sticky, or unpolymerised chromosome surfaces, due to too great a charge, and sometimes with the opposite condition of starvation. Both go with errors of spiralisation, and also of reproduction, especially in end-genes, and especially at meiosis.

Similar errors occur spontaneously at pre-meiotic divisions, and in degenerating nurse cells. The nucleic acid excess leads to an immediate hastening of mitosis but, if it is carried too far, a reaction follows and mitosis is stopped.

Fibre breakage effects. The ordinary chromosome thread is broken when the treatment occurs in the resting stage. Most of this stage is before the division or reproduction of the thread, and the result of

* A different kind of mutafacient effect is that found in the carcinogenic compounds. Malignancy which depends on a capacity for the unrestricted proliferation of cells can be induced by various reagents, especially polycyclic hydrocarbons such as methylcholanthrene and benzpyrene. These reagents may alter cell behaviour at the place of application or at distant sites; they may also affect all tissues and organs or only some, no doubt with a specific kind of activity. The transformation to malignancy is thought in the first place to be cytoplasmic both on genetic grounds (Darlington, 1944; Haddow, 1944; van Potter, 1945 ; and Woods and Du Buy, 1945) and on cytological grounds (Koller, 1947b).

Nuclear mutafacients on the other hand start reactions which quickly invade the nucleus and attack its permanent structure which is unharmed by the carcinogens. Of course, chemical agents might be found--methylcholanthrene (Strong, 1945) is perhaps of such a type-to induce permanent changes in both the nucleus and the cytoplasm, acting as nuclear and cytoplasmic mutafacients at the same time ( $c f$. M. Demerec, 1947: Nature, 159, 604). 
breakage therefore appears at the ensuing metaphase as a break in both chromatids $\left(\mathrm{B}^{\prime \prime}\right)$ and gives two types of fragment with and without centromeres $\left(\mathrm{C}_{1}{ }^{\prime \prime}\right.$ and $\left.\mathrm{C}_{0}{ }^{\prime \prime}\right)$. The broken ends of these fragments can undergo reunion $\left(R^{\prime \prime}\right)$ in new combinations to give dicentric chromosomes $\left(\mathbf{C}_{2}{ }^{\prime \prime}\right)$ or rings $\left(\mathbf{C}_{0}{ }^{\prime \prime}\right.$ or $\left.\mathbf{C}_{1}{ }^{\prime \prime}\right)$. Their constituent chromatids may also undergo separate reunion after reproduction $\left(R^{\prime}\right)$ to give configurations which visibly reveal inversions and interchanges at the ensuing metaphase. In addition, at the moment of splitting, an error may occur in the reproduction of the end-gene (or of any nucleic-acid-starved gene) giving sister-reunion (SR). Finally, after reproduction, breakage is of chromatids $\left(B^{\prime}\right)$ and reunion likewise $\left(R^{\prime}\right)$.

Prolonged low intensity X-ray doses have enabled us to separate these three groups of effect. Experiments by Koller (I946 and unpub.), using doses of $0 . \mathrm{I}, 0.25 \mathrm{r}$ and $0.5 \mathrm{r}$ per minute up to $200 \mathrm{r}$, on Tradescantia pollen grains, have shown the centromere effect clearly for the first time. They have also shown three-armed or triradial figures, due to the union of $\mathrm{B}^{\prime \prime}$ ends with $\mathrm{B}^{\prime}$ ends, in a particularly high frequency. And finally, they have shown a new concentration effect. Particular cells, or even chromosomes, in a sample suffer non-random damage. They are completely shattered. Not merely minute fragments but subminutes are formed.

Spontaneous errors are of most of the various types shown by induced errors ; but the types appear separately in different instances. It seems that the spontaneous effects are more specific. Since they do not include the concentration effect arising from prolonged treatment perhaps their specificity is due to a more specific time of action. In this regard it is notable that $\mathrm{B}^{\prime \prime}$ occurs without $\mathrm{B}^{\prime}$ in Tulipa fragrans and that centric breakage occurs at mitosis in Tradescantia but only at meiosis in Tulipa orphanidea (Darlington and Upcott, I94I).

We may expect these considerations to help, and to be helped by, the study of any new results of chemical action.

\section{(2) INTRODUCING MUSTARD GAS}

At the outbreak of the late war, research was taken up in various universities of Great Britain, Canada and, later on, the United States, in order to find antidotes for "vesicants" such as lewisite and mustard gas. At that time already some foundations had been laid. Cashmore and McCombie (r923) had already concluded that these vesicants reacted directly with the protein constituents of the cell ( $c f$. Hartwell, I946). Later it had been shown, in vitro, that oxygen consumption and glycolysis are reduced in cells after mustard gas treatment (Berenblum et al., 1936). The new work indicated that mustard gas inactivates essential cellular enzymes concerned with phosphate transfer to and from adenylic compounds ( $c f$. Gilman and Philips, I946).

For a time enzyme inactivation was considered to be the primary 
mechanism by which mustard gas affected the cell. Later, however, it was found that very weak mustard gas did not affect cell respiration, glycolysis, or those enzyme functions which depend on the phosphokinases. Yet it produced fundamental changes in the activity of the living cell. Canadian and American research also suggested that when the cells recovered after weak treatment they showed extensive damage to the nucleus. By using genetical methods, Auerbach (1943) was able to show that sulphur mustard ( $\beta \beta^{\prime}$-dichlorodiethylsulphide) induced gene changes. She obtained over 700 sexlinked lethals and many visible recessive and dominant mutations in Drosophila. Breeding tests also indicated rearrangements of chromosomes which were verified from the salivary glands of the progeny (Slizynski, 1943).

Three important points emerge from this work as summarised recently by Auerbach, Robson and Carr (1947). First, the mutations are of the same kind as those induced by X-rays. Secondly, the same treatment as gives 9 per cent. of sex-linked lethals gives only 0.5 per cent. of II-III interchanges instead of 6 per cent. as X-rays would, as though there were less rejoining of breaks. Thirdly, more than twice as many mosaics are produced as with comparable X-ray doses, and these mosaics have progeny mosaic for the same mutation as the parent, indicating a special faculty of producing unstable genes or unstable chromosomes.

In view of the importance of these discoveries, a detailed study of the direct effects of mustard gas on the chromosomes was undertaken. The raw data of the present observations were communicated to the Ministry of Supply in $1942-43$, by Koller and others, in a report which was at the time confidential.

\section{(3) METHODS OF TREATMENT}

In the first set of experiments in the summer of 1942 , root-tips, an inch long, of the onion, Allium cepa, were dipped in pure fluid mustard gas for I-30 minutes, washed in running water for I o minutes, and fixed 30 minutes, as well as 12,24 and 48 hours, after treatment. In all but the first fixation the effects on the resting and dividing cells were too drastic to be recorded even qualitatively. They had all been killed.

In the next series of experiments (1943), germinating seeds of the onion were exposed in a bell-jar to the vapour of mustard gas. Five minutes' exposure led to chromosome fragmentation, interfered with the spindle and, consequently, the anaphase movement. From these tests and those carried out on Drosophila, the use of mustard gas in vapour form seemed to be a promising method. It was used in all the further work.

In the main experiments pollen mother cells and pollen grains of the diploid Tradescantia bracteata were treated. A satisfactory apparatus 
was devised by Dr J. M. Robson. The inflorescences were kept in a small chamber through which an air current was passing at a constant rate. Vaporised mustard gas was released into the air current at intervals of 15 seconds. The mustard gas was used, either in pure, concentrated form, or diluted in cyclohexane in the ratio of 1 : ro or I : roo. The dose and time of exposure could be controlled with some accuracy. The amount of damage varied in successive experiments owing chiefly no doubt to differences in the depth of penetration of the vapour. There was no means of measuring the different amounts of the poison which might be absorbed by cells during the different stages of their development or at different depths in the anther. The qualitative conclusions, as in Auerbach's experiments, and those derived from the internal statistics of the work, are unaffected by these difficulties.

Anthers were also exposed to di- and trichloroethyl amines or nitrogen mustards. The effects obtained were similar to those induced by the sulphide. Such quantitative differences as occurred might be due to the different vapour pressures of the three substances.

Anthers were fixed in $3: \mathrm{I}$ acetic alcohol 6, 12, 24, 48, 72 and 120 hours after treatment and stained with acetic lacmoid or Feulgen's basic fuchsin. The timing is to be taken only comparatively since the temperatures varied over the range $19^{\circ}-24^{\circ} \mathrm{C}$. between night and day.

The method of treatment is given in the legends of the figures. Thus "I : roo $/ 2$ min. $/ 24$ hrs." means that the cell was treated with diluted mustard gas ( 1 : roo), exposed for 2 minutes and fixed 24 hours after treatment.

\section{(4) EFFECTS ON CELL DEVELOPMENT}

General. A gross toxic effect is quickly induced in cells at all stages of development if they are exposed to heavy doses. Clumping of metaphase chromosomes, clotting or contraction of the prophase and resting nuclei, vacuole-formation in the cytoplasm, were seen in Allium root-tips 30 minutes after exposure to the vapour of pure mustard gas. The cells did not recover, and as already noted, the whole treated portion of the root died.

In treatments of pollen grains with all degrees of dilution we can distinguish two types of nuclear change so severe as to preclude the study of breakage. The first is clotting ; a physiological wrecking, a clumping of prophase or metaphase chromosomes into a large, irregular-shaped, deeply stained body (plate II, fig. 7). From this damage pollen grains probably do not recover. The second is shattering; a mechanical wrecking, an extreme breakage of chromosomes (plate II, fig. 8). The many large and small nuclei formed after shattering cannot be expected to survive.

The proportion of pollen grains wrecked in these two ways after 
treatment with various concentrations of mustard gas are given in table $\mathrm{I}$ and fig. I. The proportions of damaged pollen mother cells

\section{TABLE I ( $c f$. fig. I)}

Percentage frequencies of cells wrecked (bold face) and merely broken (roman) as seen in mitosis after treatment with mustard gas for 2 minutes. Samples of 300 pollen grains. Temperature $19^{\circ}-24^{\circ} \mathrm{C}$.

\begin{tabular}{|c|c|c|c|c|}
\hline \multirow{2}{*}{ Strength } & \multicolumn{4}{|c|}{ Times in hours after treatment } \\
\hline & 6 & 12 & 24 & $4^{8}$ \\
\hline I : IOO & $\begin{array}{c}10 \cdot 0 \\
\ldots\end{array}$ & $\begin{array}{r}\text { I } 2 \cdot 6 \\
5 \cdot 0\end{array}$ & $\begin{array}{r}10.0 \\
12.6\end{array}$ & $\begin{array}{r}69 \cdot 3 \\
9 \cdot 3\end{array}$ \\
\hline I : Io & $\begin{array}{c}\text { II } 3 \\
\ldots\end{array}$ & $\begin{array}{l}\text { I } 6.0 \\
14.0\end{array}$ & $\begin{array}{l}19.6 \\
45.3\end{array}$ & $\begin{array}{l}45 \cdot 3 \\
34 \cdot 3\end{array}$ \\
\hline Pure & $\begin{array}{c}44^{\circ} \mathrm{o} \\
\ldots\end{array}$ & $\begin{array}{l}3 \mathrm{I} \cdot 3 \\
23 \cdot 6\end{array}$ & $\begin{array}{l}20 \cdot 3 \\
53 \cdot 0\end{array}$ & $\begin{array}{l}30 \cdot 0 \\
58.6\end{array}$ \\
\hline
\end{tabular}

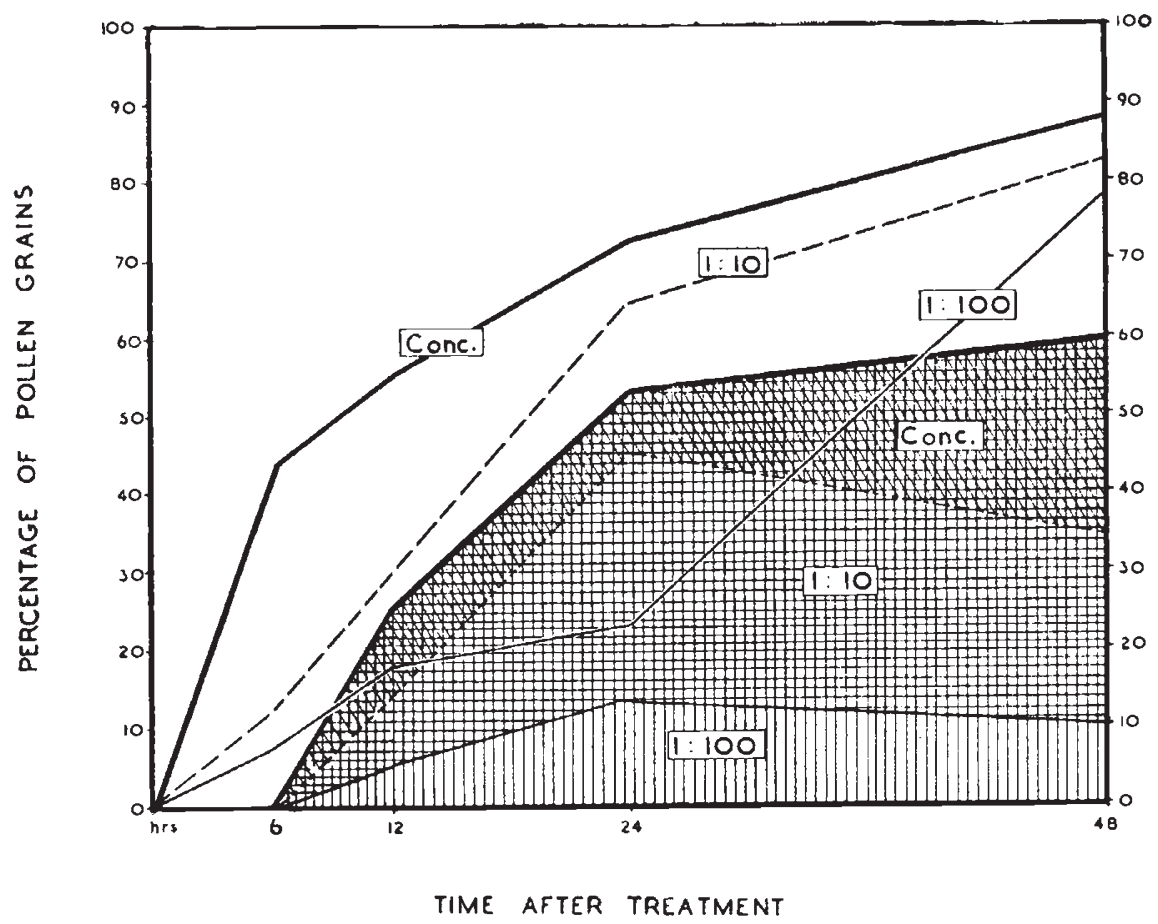

FIG. I.-The frequencies of affected pollen grains from 6 to $4^{8}$ hours after treatment with pure and diluted mustard gas. The proportion of pollen grains which are excessively damaged are shown by hatched areas.

and pollen grains increases with concentration of dose. They also increase with time up to 48 hours.

In other words the effect of the poison is cumulative. Dilute 
mustard gas has the advantage for experimental use that the frequency of recordably broken cells reaches its maximum more gradually and is always higher than that of wrecked cells.

TABLE 2 ( $f f$. fig. 2)

Percentage of metaphases $(M)$ and anaphases $(A)$ in samples of 200 pollen grains after treatment with mustard gas for 2 minutes

\begin{tabular}{|c|c|c|c|c|c|c|}
\hline \multirow{2}{*}{ Strength } & & \multicolumn{5}{|c|}{ Times after treatment in hours } \\
\hline & & Zero (control) & 6 & 12 & 24 & $4^{8}$ \\
\hline \multirow[t]{2}{*}{$1: 100$} & $\underset{A}{\mathrm{M}}$ & $\begin{array}{l}6 \cdot 5 \\
4 \cdot 0\end{array}$ & $\begin{array}{r}10.5 \\
5.0\end{array}$ & $\begin{array}{l}11.5 \\
19.5\end{array}$ & $\begin{array}{r}12.5 \\
8.5\end{array}$ & $\begin{array}{l}7.5 \\
4.5\end{array}$ \\
\hline & $T$ & 10.5 & $15 \cdot 5$ & $3 x \cdot 0$ & $21 \cdot 0$ & $12 \cdot 0$ \\
\hline \multirow[t]{2}{*}{ Conc. } & $\underset{A}{\mathrm{M}}$ & ", & $\begin{array}{r}19.5 \\
3.5\end{array}$ & $\begin{array}{r}9.5 \\
25.5\end{array}$ & $\begin{array}{r}13.5 \\
6.5\end{array}$ & $\begin{array}{l}5.5 \\
7.5\end{array}$ \\
\hline & $\mathbf{T}$ & , & $23 \cdot 0$ & $35 \cdot 0$ & $20 \cdot 0$ & $13 \cdot 0$ \\
\hline
\end{tabular}

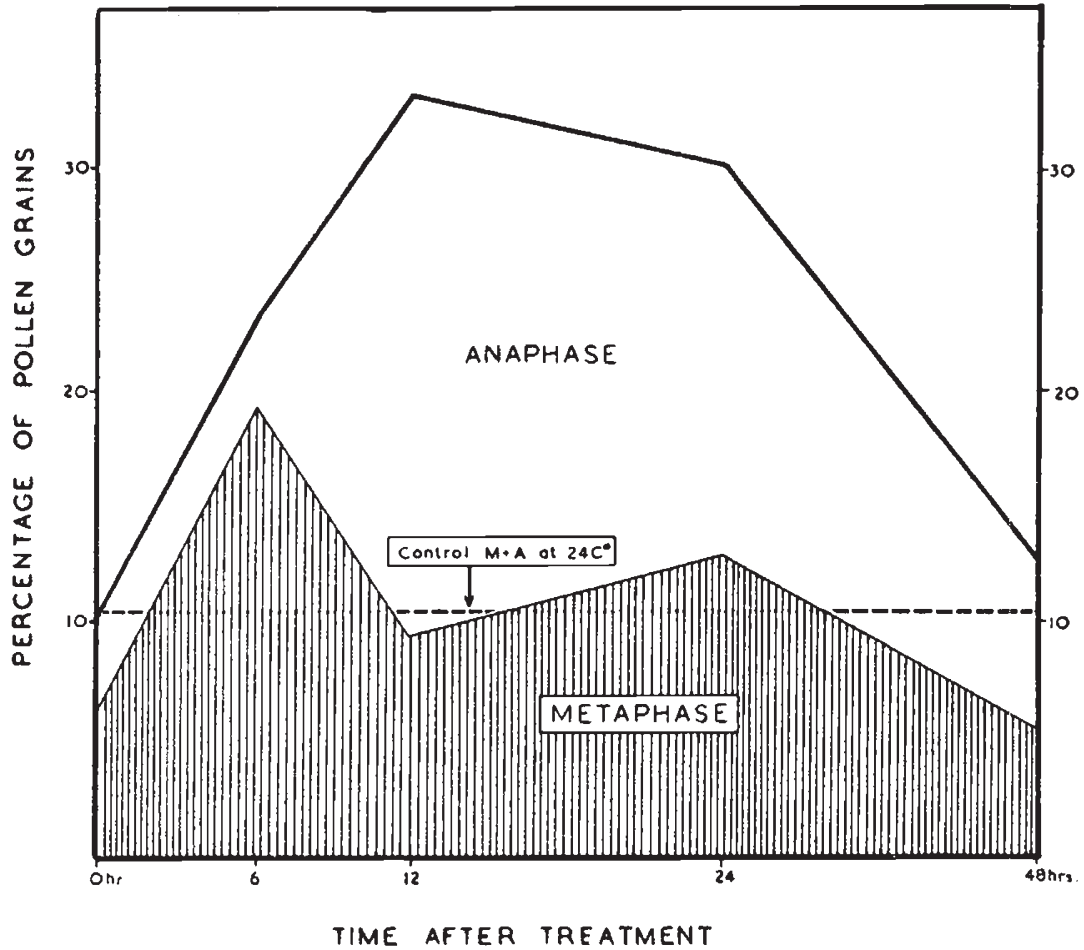

FIG. 2.- The frequencies of cells at anaphase and at metaphase at different times after treatment with pure mustard gas.

Mitosis. The frequencies of metaphases and anaphases are of course changed after treatment with mustard gas (table 2 and fig. 2). 
At $24^{\circ} \mathrm{C}$. the normal level of joint metaphase and anaphase frequency is about I0.5 per cent. in anthers of Tradescantia with 20-25 per cent. of binucleate cells. Development is only slightly less affected after treatment with dilute than with pure mustard gas. Both increase the proportion of pollen grains in metaphase and in anaphase 6 hours after treatment. This change is probably due in part to the slowing down of both these stages (as suggested by defects in spindle formation) and in part to the hastening of prophase (as suggested by the comparable X-ray experiments).

Synchronisation. Cells in the same, or nearly the same, stage of development are differently affected by treatment according, no doubt, to depth in the anther. In pollen mother-cells 24 hours after treatment the normal synchronisation within dyads is consequently upset. After 72 hours this failure of synchronisation extends even between mother-cells. Some cells were found in the first metaphase while others were already undergoing the second division. Delayed metaphases showed the severest breakage. Similar behaviour was seen in pollen grains : the division of a small proportion is delayed 3-4 days, i.e. until the generative nucleus of the sister grains is in process of differentiation.

\section{(5) EFFECTS ON THE CHROMOSOMES}

\section{(i) Qualitative}

The effects of the minimum doses on the pollen grain mitosis and on the preceding meiosis are similar in a general way. They may be grouped under the same three headings as the X-ray effects as follows ( $c f$. table 3 ).

A. Centromere effects. These appear in the first samples both in the prophase nucleus of mitosis and in the interphase nucleus of meiosis. They take the form of occasional apparent breakage leading to separation of sister chromatids at the centromere (figs. 3 and 9). But this effect can be no more than a cross-wise stretching since (in the early samples) no consequences have been seen at metaphase. The first signs of error at metaphase are a lengthwise stretching of the centromere and a failure of congression on the plate which is followed by various defects in the anaphase movement (Koller, 1947a).

Later, centromeres misdivide in mitosis as well as in meiosis. Also single chromatids can break off a centromere at anaphase. Later still, this breakage is sometimes found at metaphase in mitosis. It seems always to be followed by reunion with another centromere, or end, or even union with the middle of a chromosome. Such reunion is due presumably to a nucleic acid and not a protein fibre connection, since it does not seem to survive in any anaphase configuration. In the later samples anaphase movement becomes more defective; chromosomes lag and extra nuclei appear at telophase; wall-formation may fail in the pollen mother cell. 


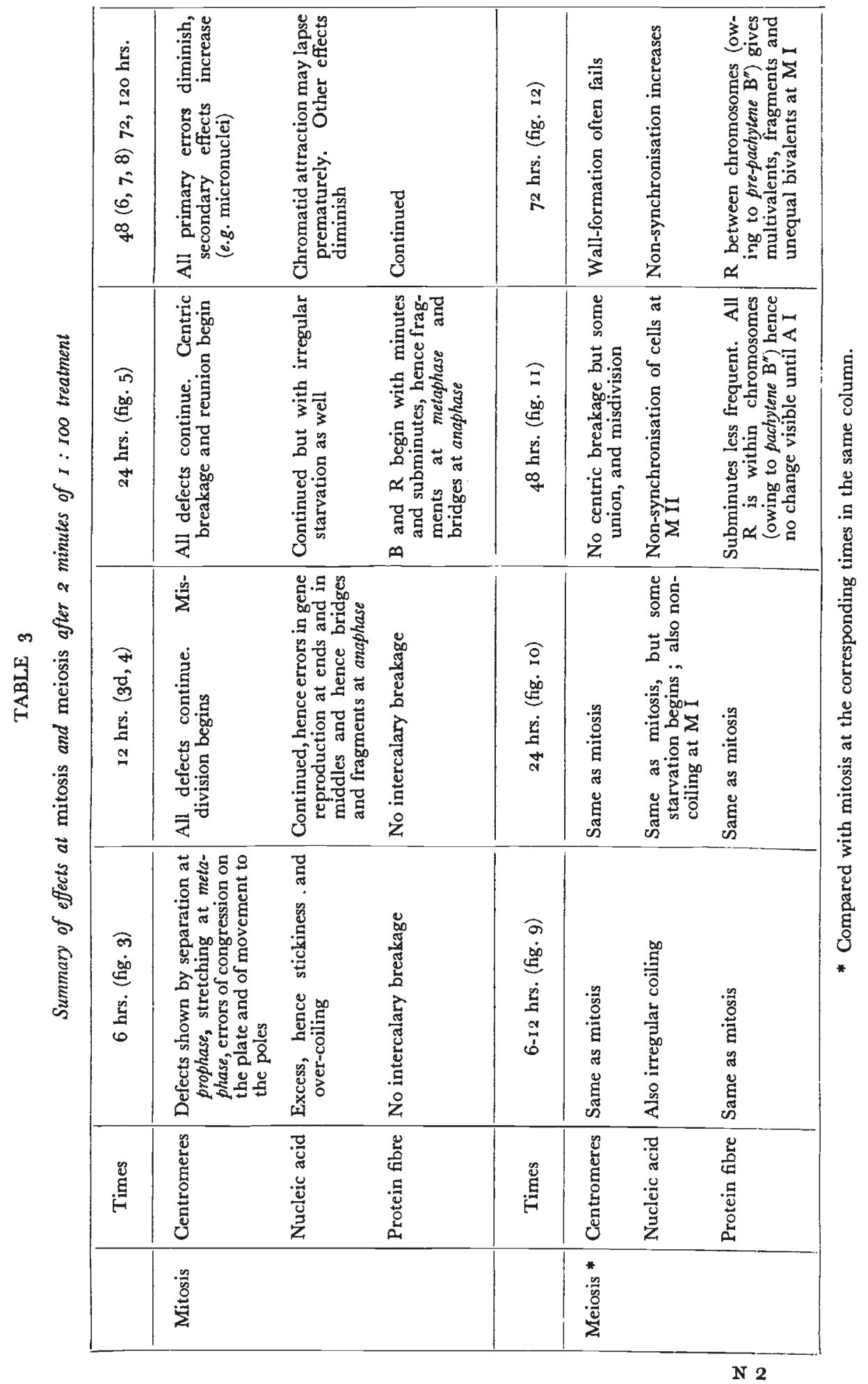


B. Nucleic acid effects. The first samples show an excessive nucleic acid charge associated as usual with stickiness and often with irregular coiling so that the spiral becomes externally obvious. Later these errors increase and, in consequence, at meiosis there is some breakdown
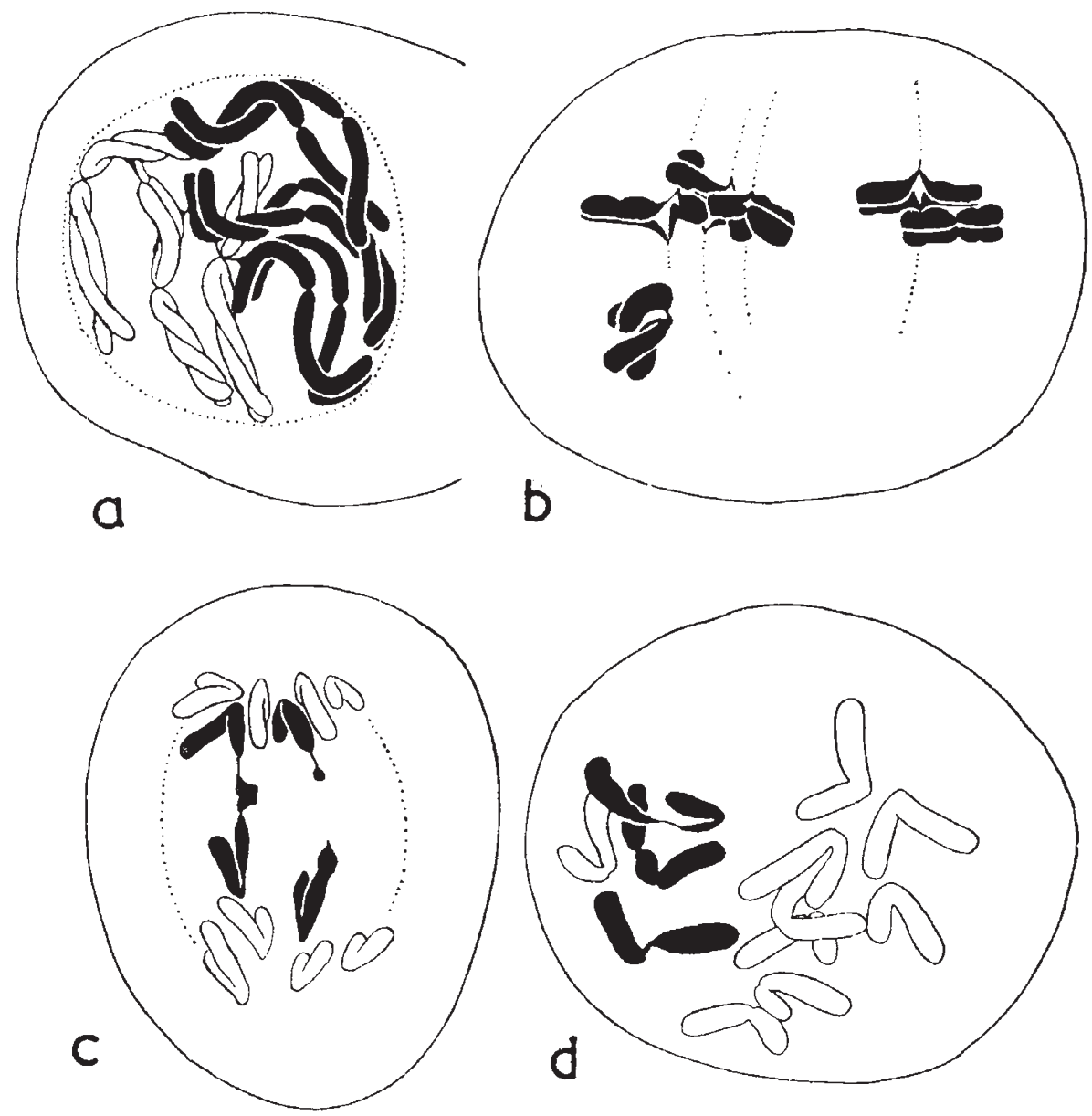

Fig. 3.-(a) Prophase of mitosis in treated pollen grains showing separation of centromeres and stickiness at the centromeres and ends. ( $1: 10 / 2 \mathrm{~min} . / 6 \mathrm{hrs}$.)

(b) Metaphase : supercontraction of chromosomes, lack of synchronisation in the division of centromeres in different chromosomes and unorientated chromosome in which the centromere is delayed. ( $\mathrm{I}: \mathrm{ro} / 2 \mathrm{~min} .6 \mathrm{hrs}$.)

(c) Anaphase : defective reproduction of chromosomes, local non-spiralisation, and possibly a broken bridge. (I : 100/2 min./6 hrs.)

(d) Anaphase without spindle : some of the chromosomes show stretching at the centromere. (I : $100 / 2 \mathrm{~min} . / 12 \mathrm{hrs}$.)

All drawings are magnified 1900 diameters.

of major coiling such as results from heat shock (Darlington and La Cour, 1947). The opposite condition, nucleic acid starvation, also develops sporadically but this is more characteristic of high doses. 
Two secondary effects are referable to nucleic acid derangement. One is the failure of synchronisation already noted at the second metaphase of meiosis. The other, seen especially at mitosis, is the failure of gene reproduction and consequently of chromatid separation. This failure, as after cold treatment, is both terminal and intercalary. The one gives rise to bridges, the other to fragments as well.

A premature failure of chromatid attraction at metaphase of mitosis (giving it the appearance of a second meiotic metaphase) is perhaps due to an error of control by the centromere of nucleic acid charges.

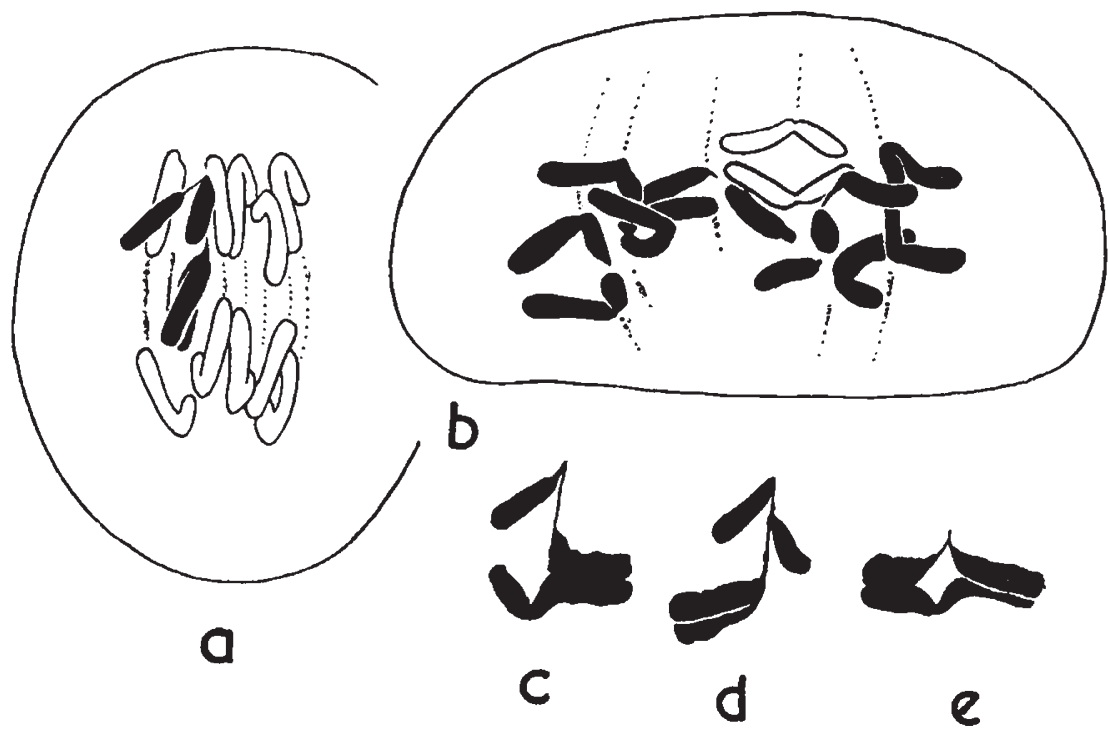

FIG. 4.-(a) and (b) Anaphase : stretching and misdivision of the centromere. Dicentric chromatids in $(b)$ are formed by non-division of an unbroken end. (1 : 100/2 min./12 hrs.)

$(c),(d)$, and $(e)$.-Failure of chromatid reproduction accompanied by stretching and misdivision of the centromere. ( $1: 100 / 2 \mathrm{~min} . / 12 \mathrm{hrs}$.)

C. Protein fibre effects. These consist in the breakage of the genestring otherwise than at the centromere. The breakage takes place inside the resting inter-mitotic nucleus. In consequence its effects are not seen at metaphase of mitosis until 24 hours after treatment.

Apart from large fragments, minutes are formed. They are common at mitosis, rare at meiosis. The two types found with X-ray breakage are recognisable and with similar frequencies, namely (i) those lying unattached and assumed to have undergone $R^{\prime \prime}$ to form rings, and (ii) those attached to major chromosomes by prophase reunion and assumed to have undergone $\mathrm{R}^{\prime}$ at one end and perhaps $\mathrm{SR}$ at the other (plate II, figs. $7 e, 8 a$ ). The highest frequency of these two types is at 72 hours.

In addition to the ordinary minutes there is a class of smaller 
subminutes. These are especially abundant 24 hours after treatment and gradually fade away in the later samples. The fact that the subminutes never appear to be double we attribute to their small size. If attractions are a function of mass and repulsions of surface, the attractions would cease to be effective below a certain size ( $c f$. Darlington, 1937 ; fig. I 39).

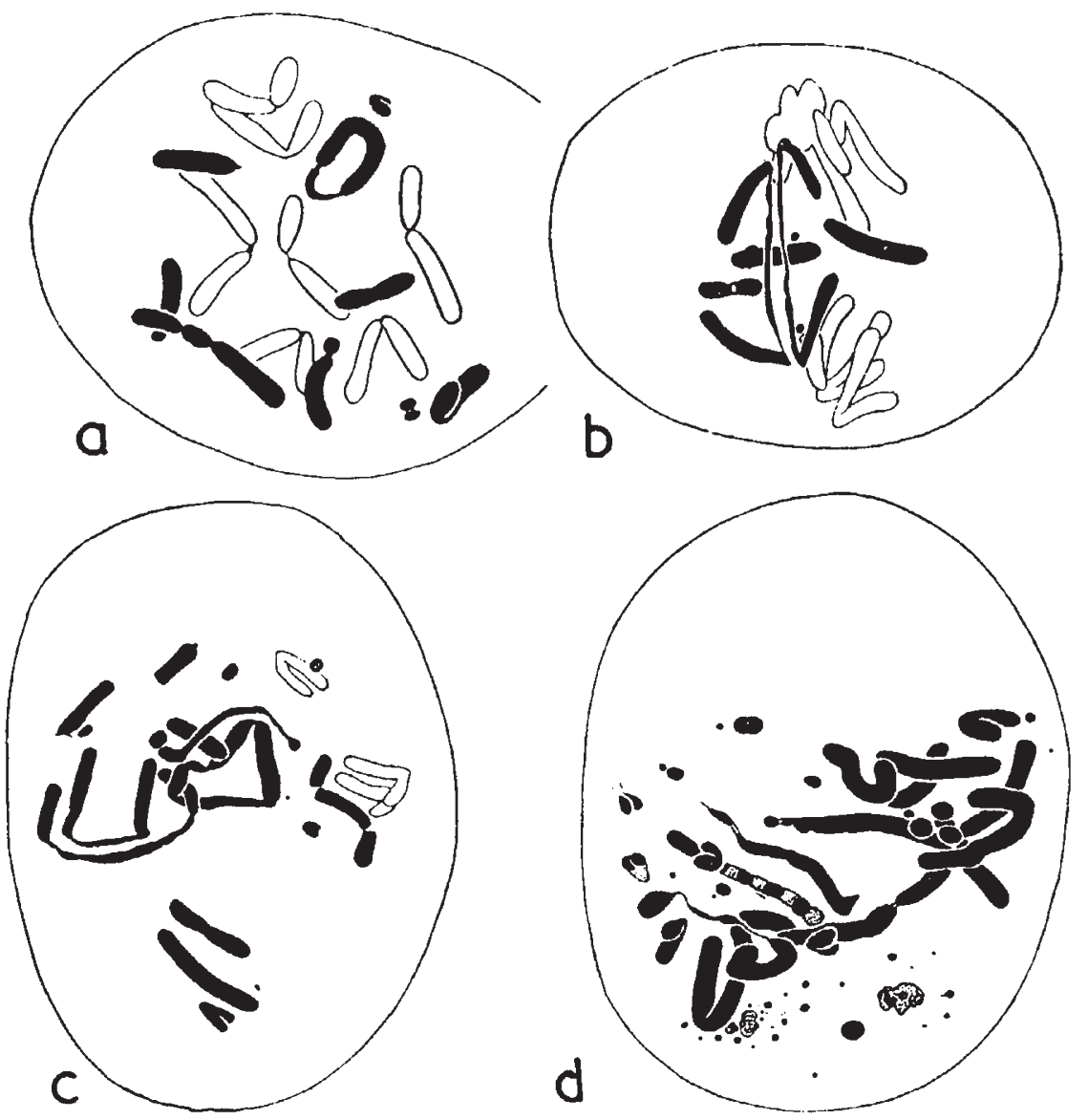

Frg. 5.- $(a),(b)$, and $(c)$. Anaphases with defective spindles, with dicentric chromosomes, centromere breaks of chromatids, bridges, acentric and minute fragments. (a) Shows a subspiralisea segment not under tension. ( $1:$ ro/3 min./24 hrs.)

(d) Extreme chromosome fragmentation or shattering. Many of the fragments are very small, "subminutes." Some chromosome regions and fragments are starved of nucleic acid. (Pure mustard gas/2 min./24 hrs.)

Subminutes may be free globules of nucleic acid, but since they survive at telophase and since they are relatively infrequent at meiosis, where the minutes are also infrequent, we prefer to suppose that they are true chromosome fragments (containing protein fibre).

In X-rayed mitosis a proportion of ends produced by $\mathrm{B}^{\prime \prime}$ reunite with the opposite ends produced by a single $B^{\prime}$ to give triradial figures. 
These are most significant. They show that $\mathrm{B}^{\prime \prime}$, formed before the reproduction of the gene-string, can remain open and unhealed long enough to reunite after its reproduction. Still more significant are certain triradials which arise where unbroken ends (no fragments being present) have behaved like $\mathrm{B}^{\prime \prime}$ ends. These show that unbroken ends can undergo union in special circumstances. We already know that

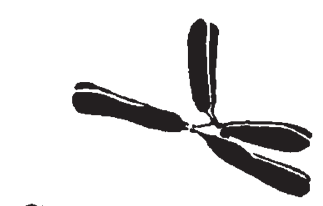

a

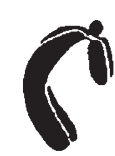

b

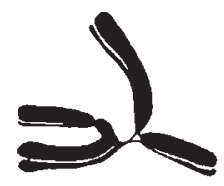

C
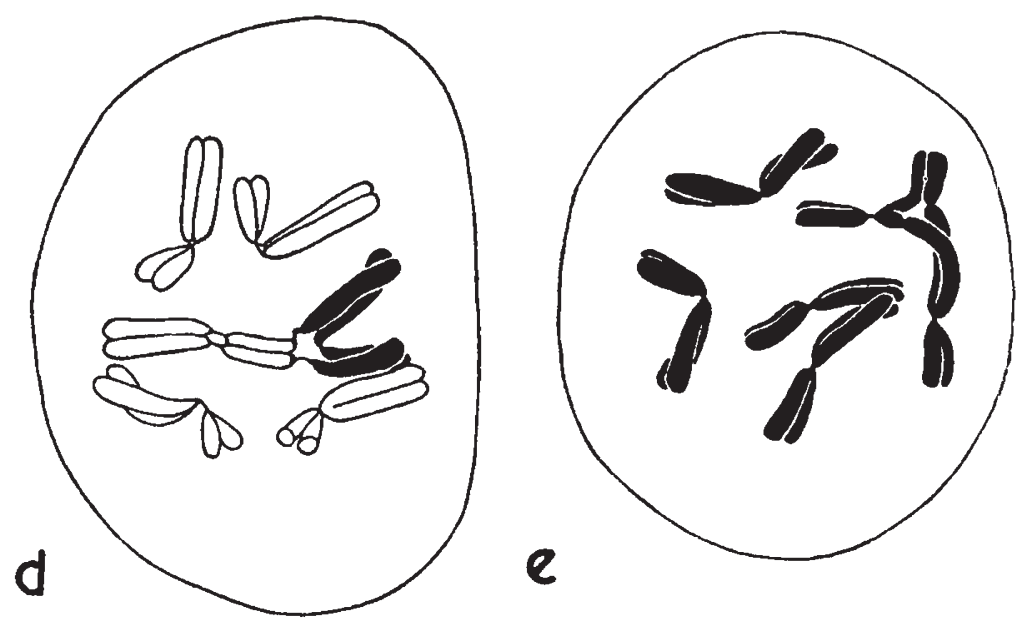

FiG. 6.-(a), (b), and (c). Various types of centric reunion.

(d) Metaphase : one chromsome shows centric chromatid break with terminal reunion. (1 : $100 / 2 \mathrm{~min} . / 4^{8} \mathrm{hrs}$. )

(e) Metaphase with one $\mathrm{B}^{\prime}$ followed by union of the broken ends with two unbroken chromatid ends to give the triradial figure. The union has not established joint spiralisation and so must be a prophase reunion. (Cf. plate II, fig. I I). (1: 100/ $4 \mathrm{~min} . / 4^{8} \mathrm{hrs}$.)

they can undergo SR, as broken ends do, when the nucleic acid metabolism is upset. It seems, therefore, that such an upset arising from irradiation is responsible for the fusability by $R^{\prime}$ of unbroken ends.

Now we find that triradials from both causes are much more frequent after mustard gas treatment than after short intense $\mathrm{X}$-raying (tables 4 and 5 , figs. $7 \mathrm{e}, 8 \mathrm{~b}$ and $8 \mathrm{c}$, broken ends ; and 6e, unbroken ends). The reasons for this are presumably twofold. First, $B^{\prime}$ and $B^{\prime \prime}$ are formed directly one after the other in the same cell, whereas with short X-raying they occur together only when one chromatid 


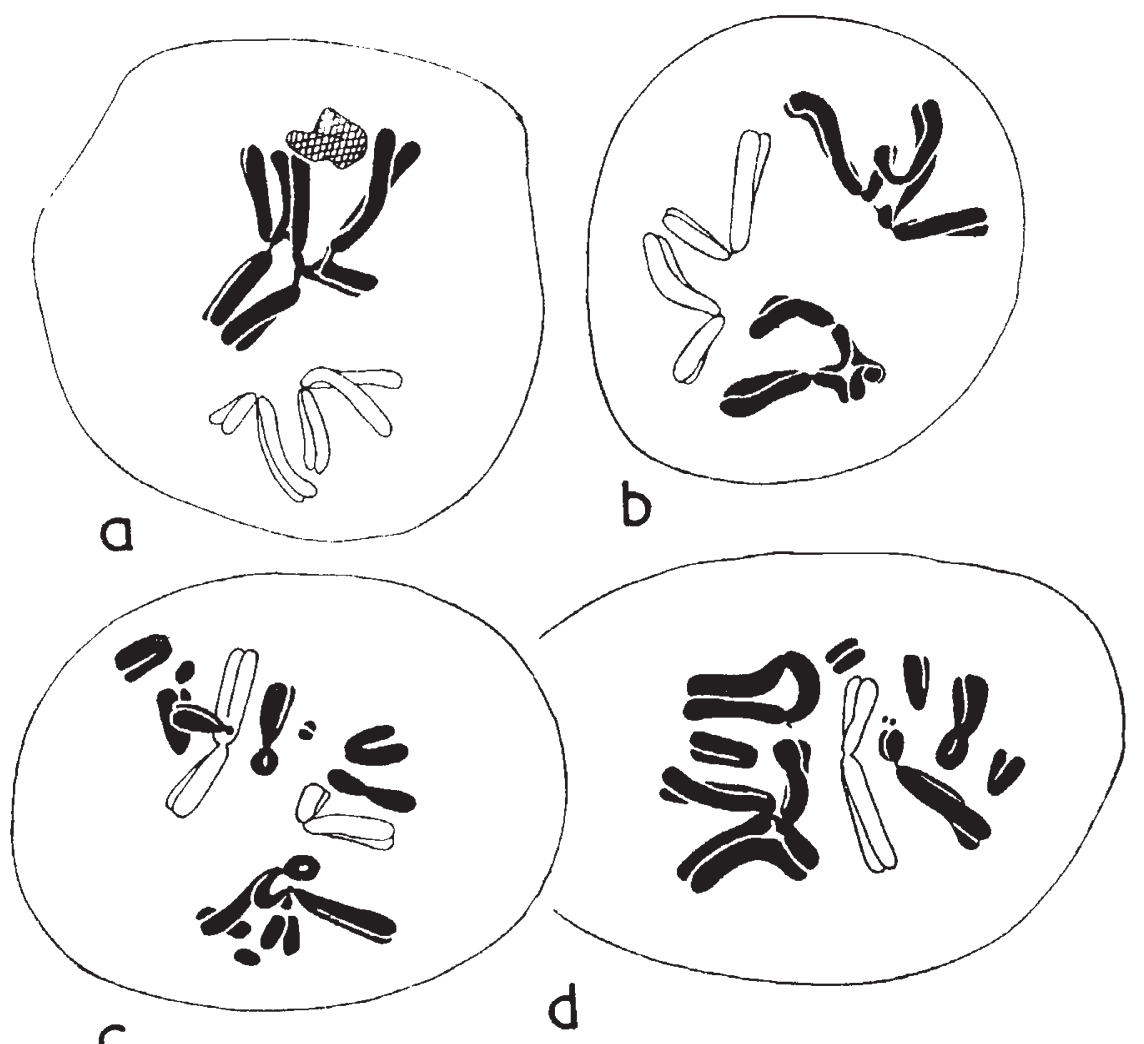

C

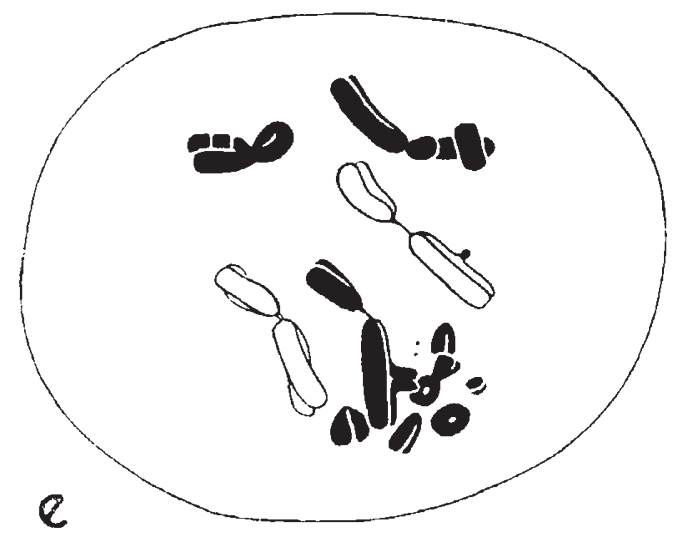

FIG. 7.--Metaphases in pollen grains showing the combination of centric and intercalary breakage and reunion. ( $1: 100 / 2 \mathrm{~min} . / 4^{8} \mathrm{hrs}$.)

(a) A collapsed chromosome and multiple centric reunion.

(b) Two chromatid interchanges $\left(2 \mathrm{~B}^{\prime}+2 \mathrm{R}^{\prime}\right)$.

(c) $\mathrm{B}^{\prime}$ and $\mathrm{B}^{\prime \prime}$ followed by $\mathrm{SR}$ and $\mathrm{R}^{\prime \prime}$.

(d) The foregoing together with premature dissolution of a centromere.

(e) Prophase and triradial figures, stretched centromeres, etc. 
from a $B^{\prime \prime}$ undergoes restitution leaving the other open as a spurious $B^{\prime}$ along with genuine B"s. Secondly, the nucleic acid upset can have taken effect on the unbroken ends by the time the chromatid with which they are to unite is broken. The upset by itself provides twelve joinable ends all ready to fuse with any true breaks that may later turn up. Both these differences arise from the prolongation of treatment and not from the kind of treatment.

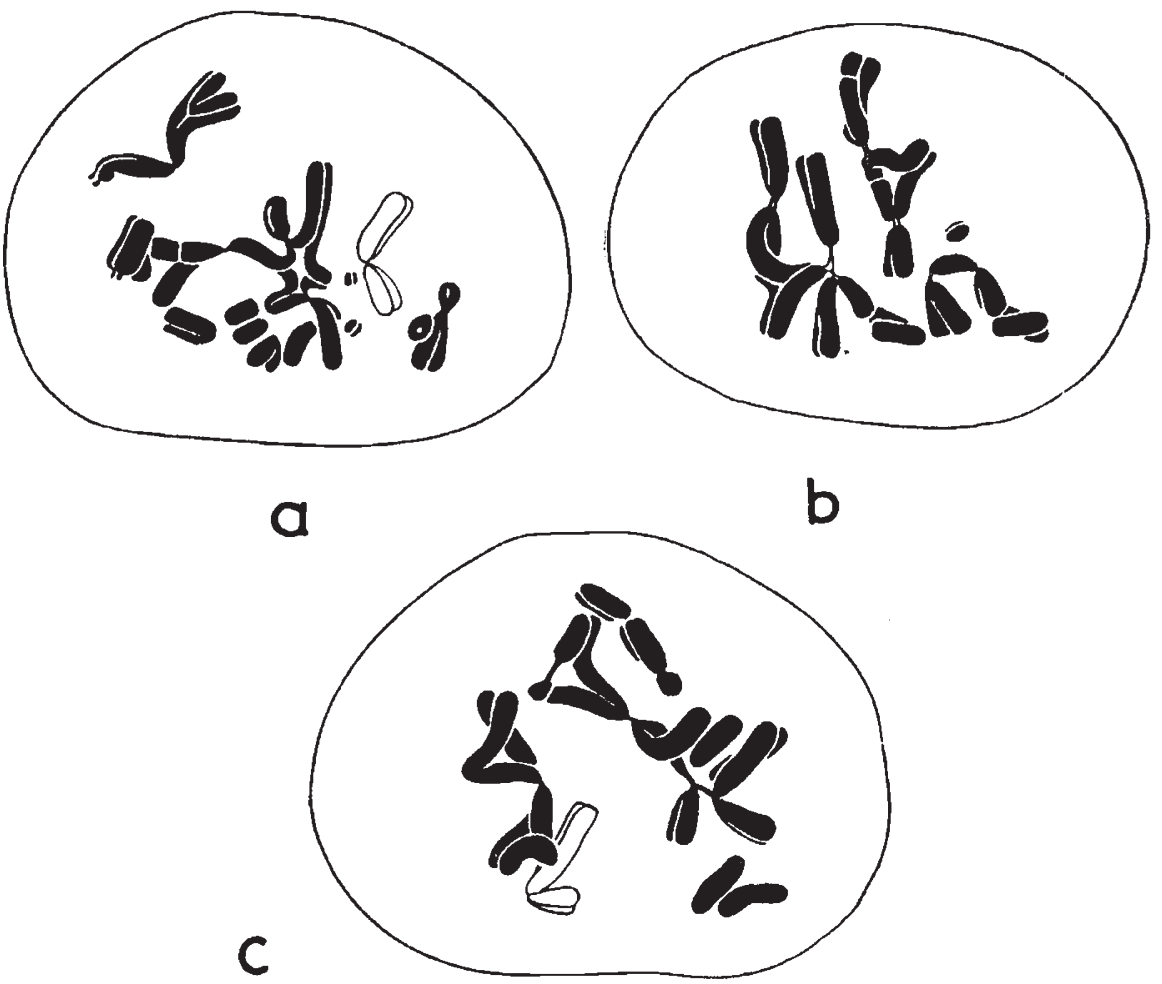

Fig. 8.-Metaphases in pollen grains showing triradials. ( $1: 100 / 2 \mathrm{~min} . / 72 \mathrm{hrs}$ )

(a) B" followed by $\mathbf{R}^{\prime \prime}$, SR and $\mathbf{R}^{\prime}$.

(b) and $(c)$. $\mathbf{B}^{\prime}$ and $\mathbf{B}^{\prime \prime}$ followed by $\mathbf{R}^{\prime}$. Some centric unions.

In meiosis the effects of fragmentation do not appear for an even longer time than in mitosis and then in two stages. First, we find fragmentation at anaphase only and with no abnormalities at metaphase. Later, we find fragments, multivalents and unequal bivalents, at metaphase. Now a sequence of three stages in the conditions of breakage and reunion would be expected at meiosis :

(i) post-pachytene ; $\mathbf{B}^{\prime}$ only ; no reunion except by crossing-over ; no free fragments until the lapse of chromatid attraction at anaphase ;

(ii) pachytene ; $\mathrm{B}^{\prime \prime}$ with no reunion between chromosomes but free fragments at metaphase ; 
(iii) pre-pachytene ; $\mathrm{B}^{\prime \prime}$ with free reunion giving multivalents visible at metaphase.

The end terms of this sequence are clearly distinguishable as indeed they also are with X-ray treatments of the same material (La Cour, r946).
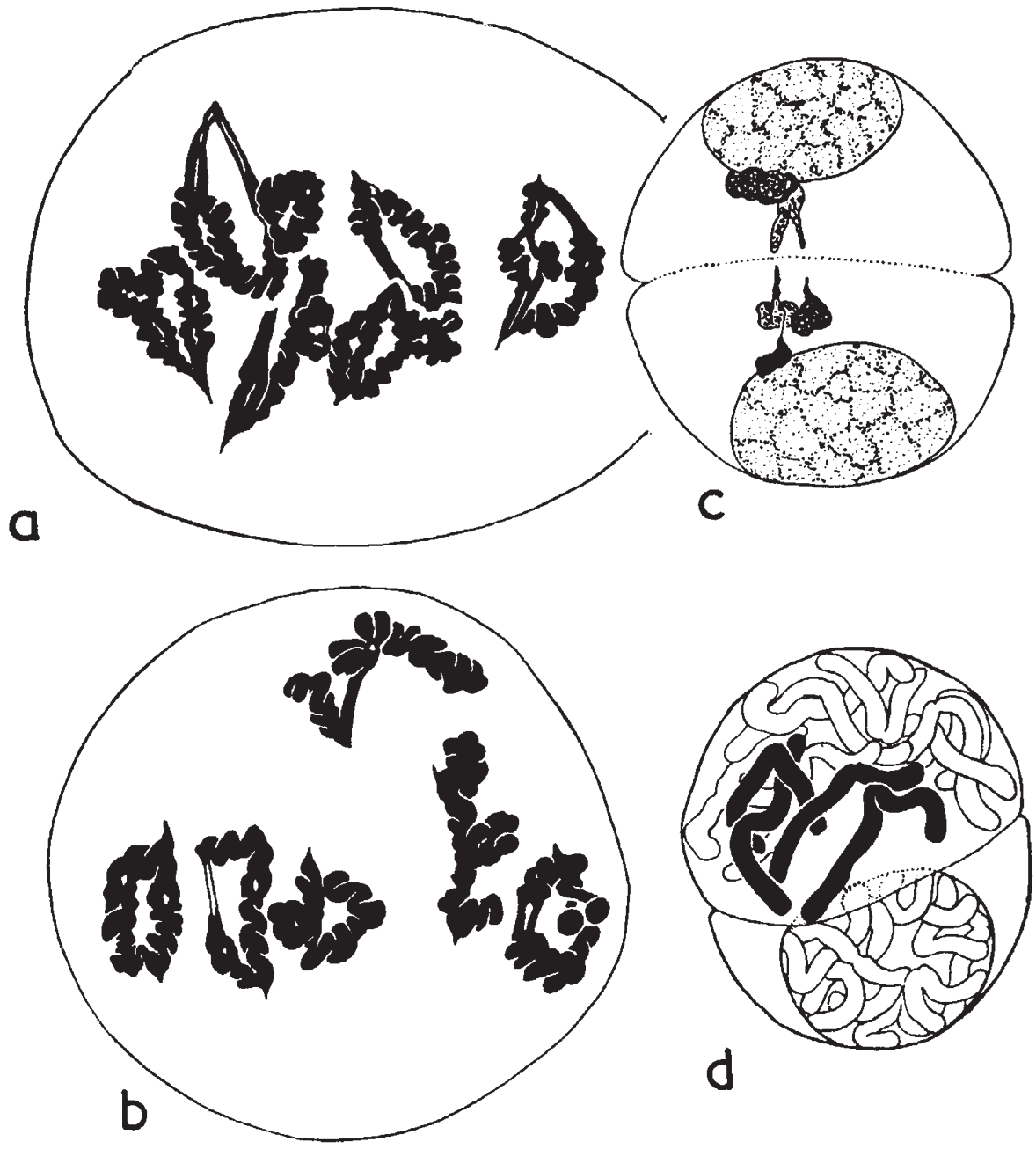

FIG. 9.-Treated pollen mother cells.

(a) Metaphase I with irregular coiling. (Pure/2 min./6 hrs.)

(b) The same. (I : roo/2 min./12 hrs.)

(c) Lagging chromosomes, excluded from the interphase nuclei. (I : I oo/2 min./1 $2 \mathrm{hrs}$.)

(d) Apparent precocious division of centromeres during prophase of second division.

(I : $100 / 2 \mathrm{~min} . / 12 \mathrm{hrs}$.)

Thus breakage takes place at prophase of meiosis when the stretched thread between chromomeres is naked and unprotected, although not at prophase of mitosis when the chromosomes are uniformly clothed with nucleic acid. 


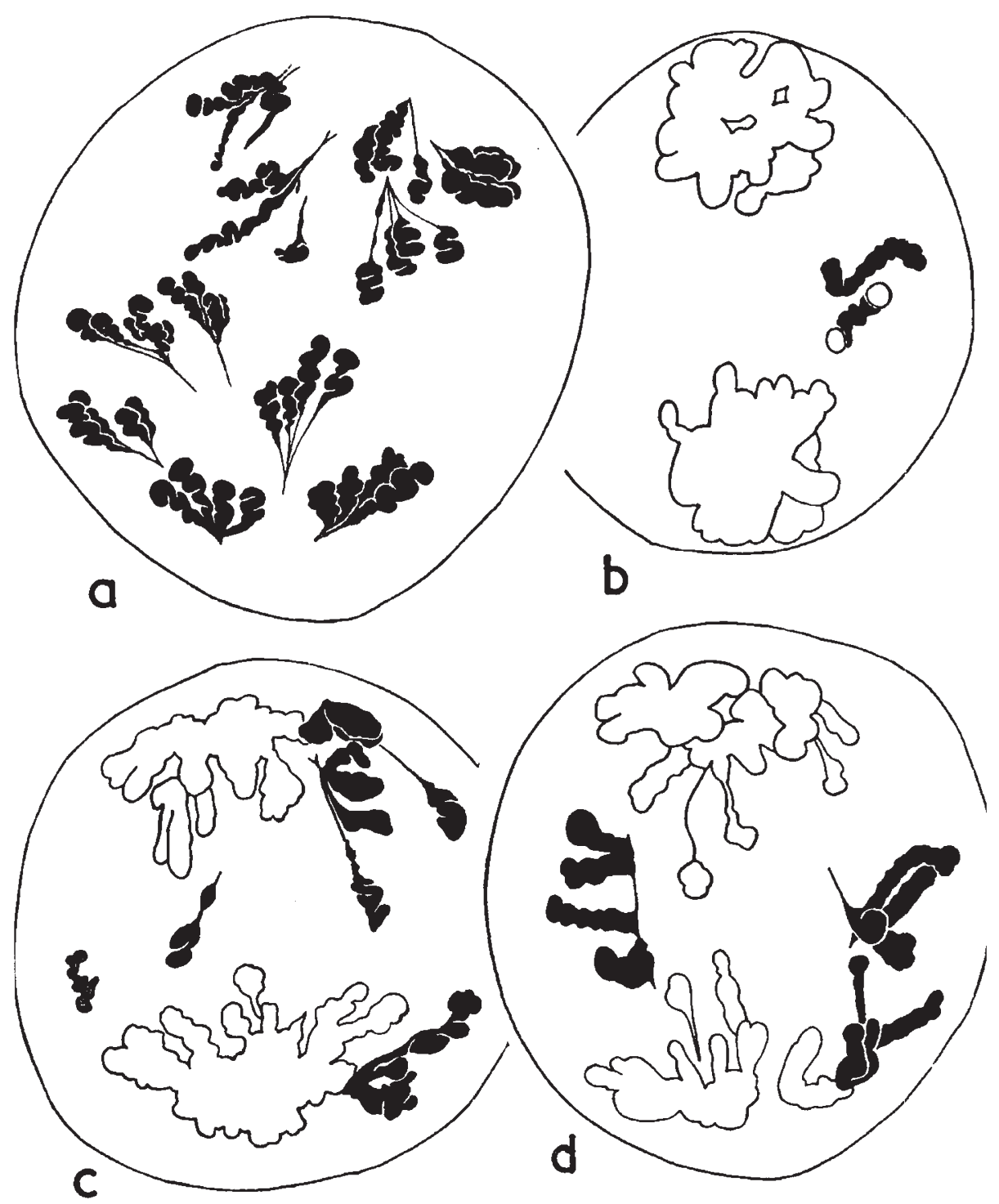

Fig. 10.- (a) Anaphase I : abnormal stretching and breaking at the centromere, irregular spiralisation. ( $1: 100 / 3 \mathrm{~min} . / 24 \mathrm{hrs}$. )

(b) Univalent at telophase I : it has divided, and the chromatids show imperfect spiralisation. (1 : 100/3 $\mathrm{min} . / 24 \mathrm{hrs}$.)

(c) Anaphase I : breakages at the centromere regions. One acentric fragment shows nucleic acid starvation. (1 : 100/3 min./24 hrs.)

(d) Anaphase I : misdivision of the centromere, and stretching of the centromere region (1: $100 / 3 \mathrm{~min} . / 24 \mathrm{hrs}$. ) 
The seriation of stages is not of course as exact with mustard gas as with terminable treatments. Action being, as we saw, cumulative, all the more deferred observations include the less deferred. All effects seen after 24 hours can also be seen after 48 hours. Nevertheless a characteristic difference in timing appears between mitosis and
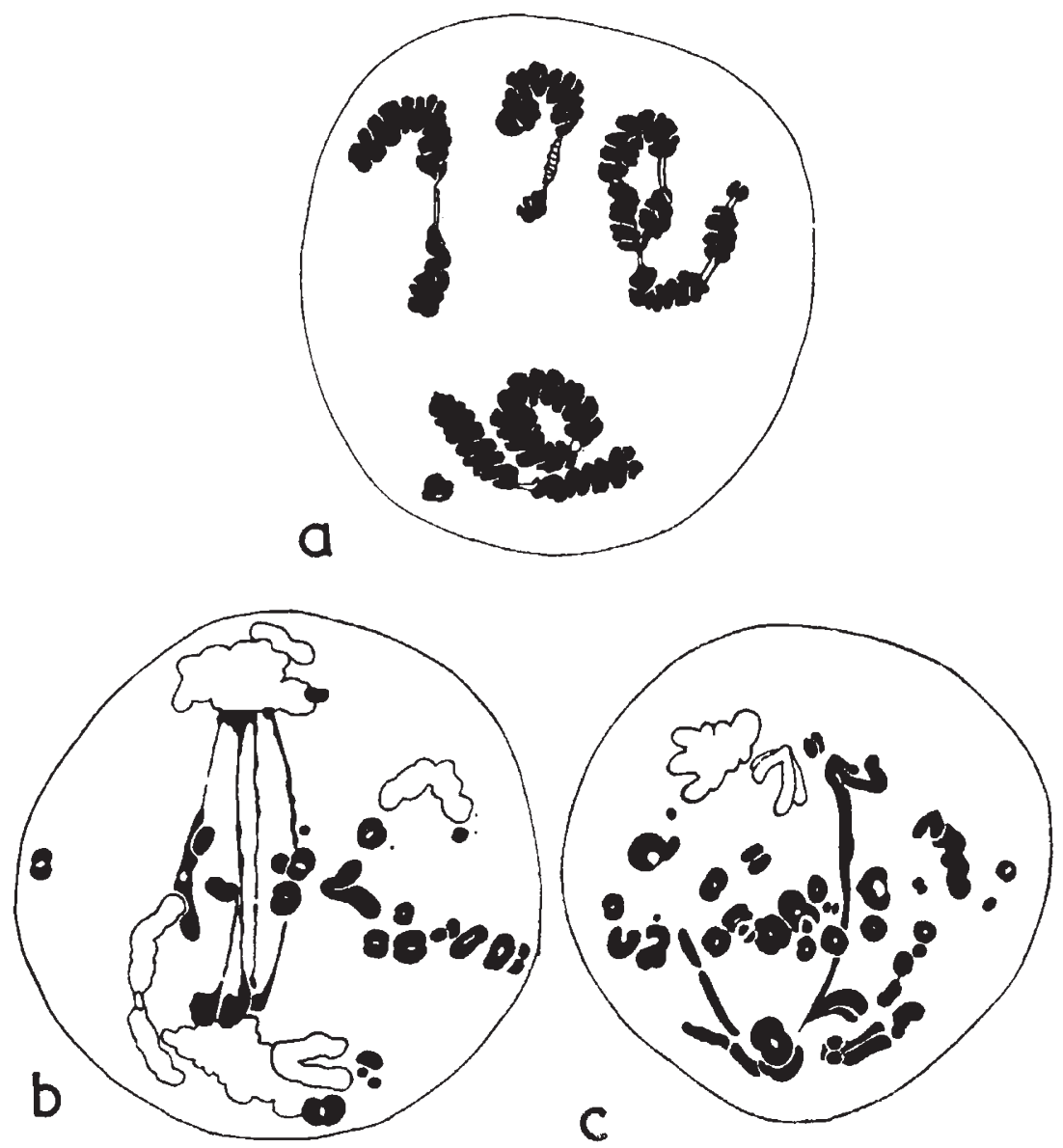

Frg. II $(a)$. Metaphase I : nucleic acid starvation and uncoiling, fragmentation and centric union (plate I, fig. 4).

$(b)$ and $(c)$. Anaphase I: acentric fragments, minutes and subminutes, bridges, and delayed separation of bivalents. (I: $100 / 2 \mathrm{~min} . / 48 \mathrm{hrs}$.)

Note the contrast in amount of visible breakage at metaphase and at anaphase.

meiosis as shown by the method of correlation used in table 3. Only after 48 hours does the meiotic series begin to show the breakage which appears in the mitotic series after 24 hours. This difference is in keeping with the known prolongation of the prophase in meiosis as compared with mitosis.

Again the centromeres show no breakage or reunion at first metaphase of meiosis. Presumably they are not undergoing division 

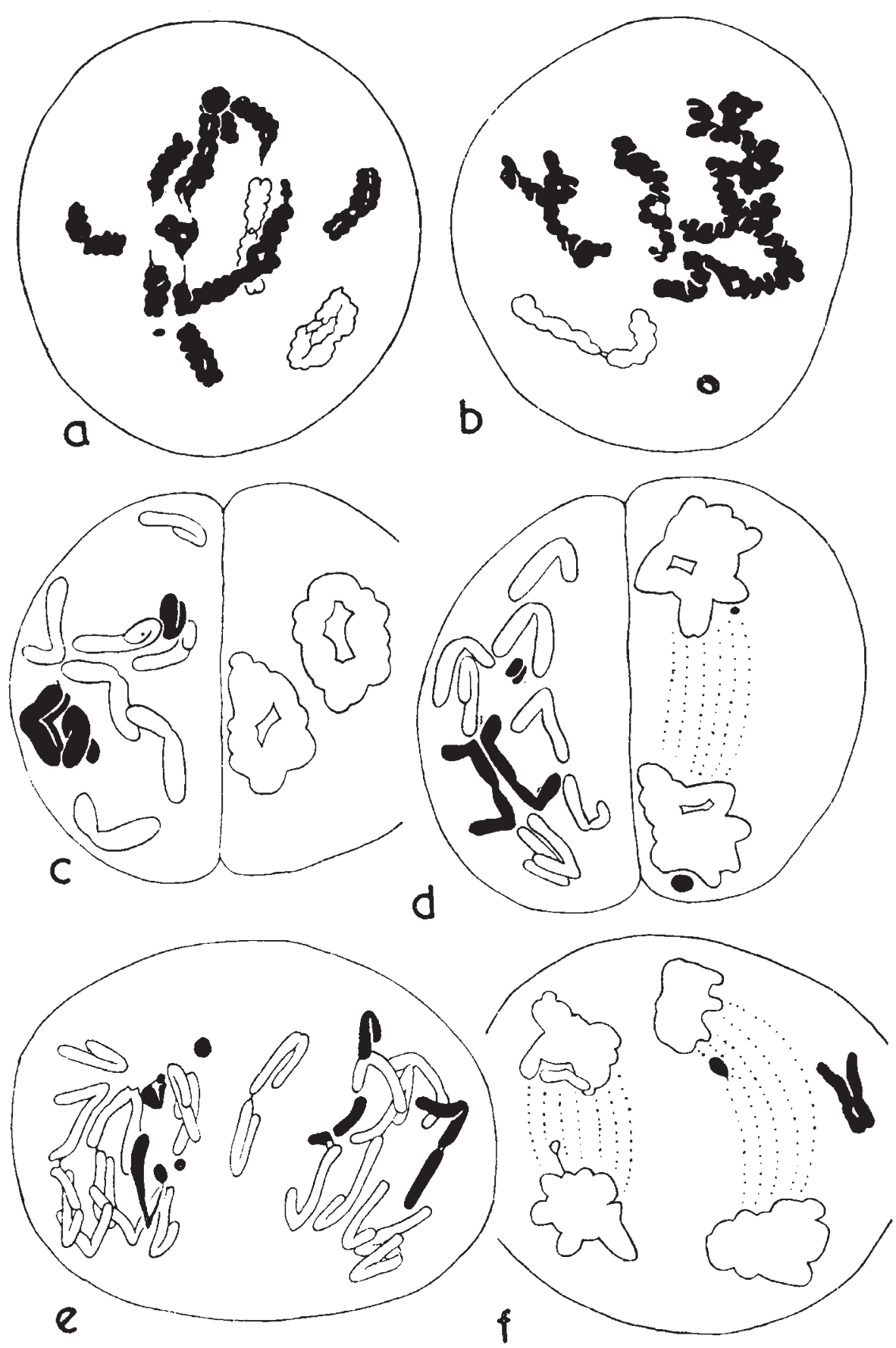

Fig. 12.- $(a)$ and (b). Metaphase I : multivalents, unequal bivalents, and acentric fragments in cells with low breakage. ( $x: x 00 / 3 \mathrm{~min} . / 72 \mathrm{hrs}$.)

(c) Anaphase II : lack of synchronisation and of spindle formation on one side; the chromosomes have fallen apart but fail to move towards the poles. Dicentric chromosomes and acentric fragments are present. (1: 100/3 min./72 hrs.)

(d) Abnormal distribution of chromosomes at anaphase II, with dicentrics. One member of the dyads is in telophase, while the other is in anaphase. (1: $100 / 3 \mathrm{~min} . / 72 \mathrm{hrs}$.)

(e) Failure of wall-formation at the end of first division leads to the formation of a polyploid cell. Fragments are present. One chromosome shows stretching at the centromere, others show stickiness. (1 : 100/3 min. $/ 72 \mathrm{hrs}$ )

( $f$ ) Abnormal tetrad, without a wall between the cells. One chromosome is left behind with the centromere still undivided. ( $1: 100 / 3 \mathrm{~min} . / 72 \mathrm{hrs}$.) 
and are therefore less exposed to the greatest danger which is that of damaging themselves by misdivision. The other differences between mitosis and meiosis are likewise in keeping with the known differences in the timing of the division of the centromere and in the pairing and coiling of the chromosomes.

\section{(ii) Quantitative : Mitosis}

Mitoses in the pollen grains were recorded quantitatively 48, 72 and 120 hours after treatment. At $4^{8}$ hours, $9^{\cdot 2}$ per cent. of cells were too badly injured for interpretation, so that we had to be content with a biassed sample of 90.8 per cent. The later samples were complete and unbiassed.

Comparison with X-rays enables us to standardise the mustard gas dose. With pollen grains, 2 minutes of 1 : 100 mustard gas treatment is approximately equivalent to $360 \mathrm{r}$ (fig. $13, c f$. Darlington and

TABLE 4

Breakage and reunion of chromosomes following treatment with mustard gas I : $100\left(24^{\circ}\right) 2$ minutes; pollen grains of $\mathrm{T}$. bracteata (cf. fig. 13)

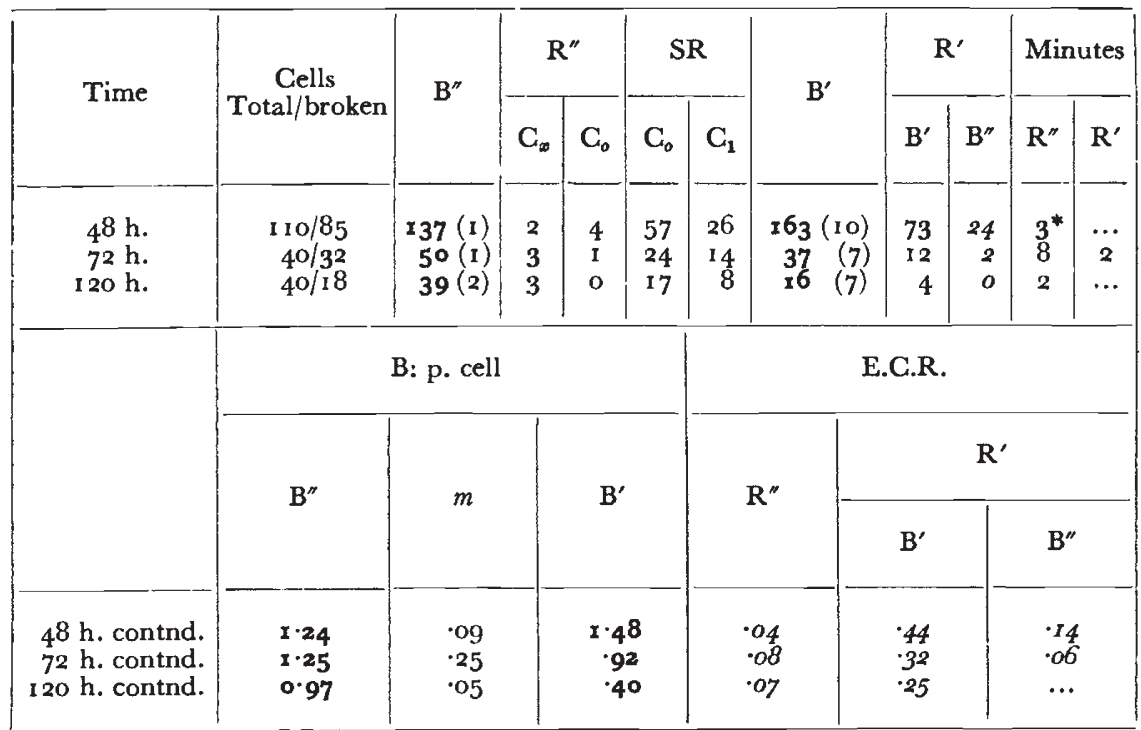

* In addition 7 subminutes in one cell.

Notes.- $\mathrm{B}^{\prime \prime}$ includes (i) free acentrics, (ii) those which have undergone $\mathrm{R}^{\prime}$ to give triradials, (iii) a small proportion of unscorable token breaks where unbroken ends have united by $R^{\prime}$ to give triradials.

Brackets after $B^{\prime}$ and $B^{\prime \prime}$ enclose additional centric breaks excluded from the analysis of ordinary breakage. E.C.R., Empirical Coefficient of Reunion of breaks.

La Cour, 1945). With Drosophila sperm Auerbach (unpub.) finds that I4 minutes of $\mathrm{I}$ : Io mustard gas treatment, using the same chamber and dilution, is equivalent to about $5000 \mathrm{r}$. The measurement is by 
chromosome breaks in the one case and by sex-linked lethals, which are mostly no doubt related to breakage, in the other. Allowing for a lower permeability of flies than flowers, the mustard gas treatment can, it seems, be measured more accurately than was expected and even quantitatively the analogy between the two treatments holds.

Breakage (table 4 and fig. 13 ). The average frequencies of breakage $\left(B^{\prime \prime}, B^{\prime}\right.$ and $\mathrm{m}$ ) agree fairly well with those produced in Tradescantia

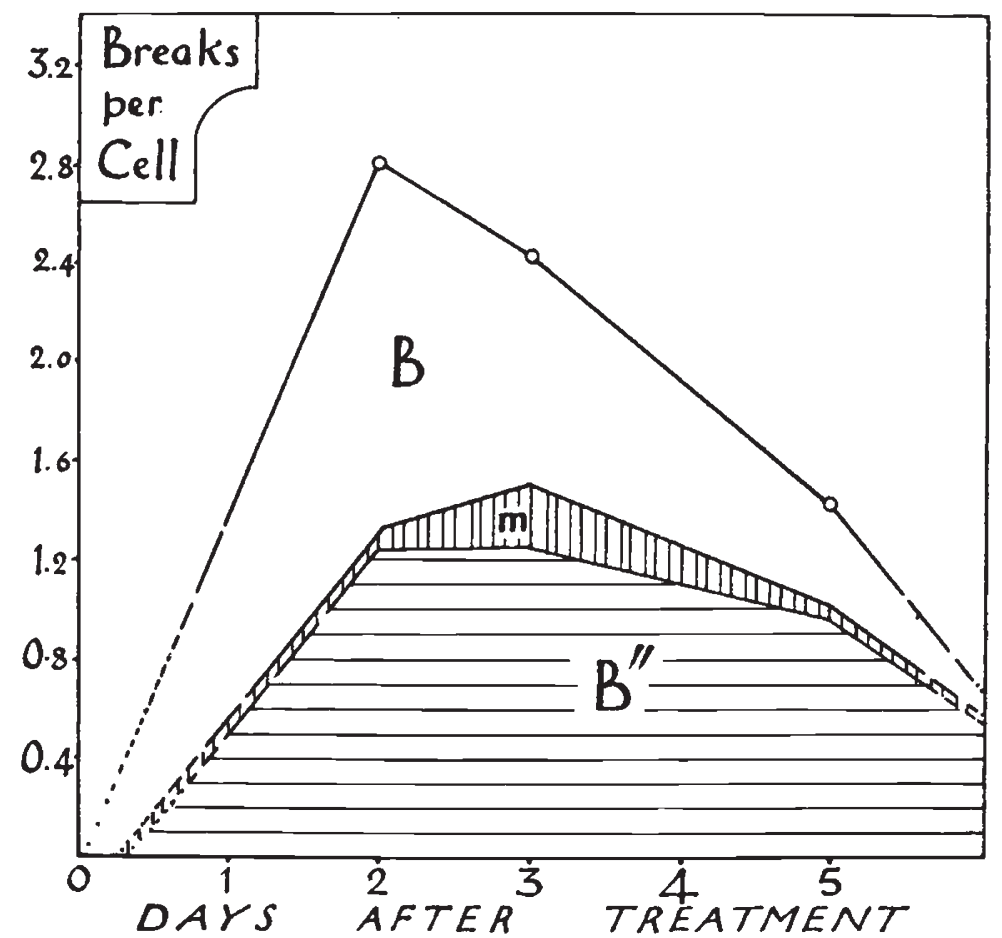

Fig. 13.-Graph showing breakage frequencies $\left(B^{\prime}, B^{\prime \prime}\right.$ and minutes) at different times after mustard gas treatment of pollen (with delayed effect) showing the analogy with X-ray treatment of roots (with differential development effect) as shown in Darlington and La Cour (1945), graph 6.

pollen by $360 \mathrm{r}$. The time curve, however, agrees rather with that produced at the same temperature by $45 \mathrm{r}$ on Trillium erectum roottips : the abrupt and clear changes found with X-ray treatment of pollen are no longer traceable. The reason for this is, again, that mustard gas, like low intensity radiation, has a continuous effect which acts like the dispersal due to different rates of cell development in the root-tip in blurring the differentiation by time. In addition to this external blurring, there is the internal blurring which is inherent in all breakage and comes about because the apparent chromatid breaks $\left(\mathbf{B}^{\prime}\right)$ arising from treatment at all these stages are both original $B^{\prime}$ and those surviving from $B^{\prime \prime}$ after $R^{\prime}$. 
The X-ray effects on pollen have shown that the true or direct chromatid breakage occurs at the most sensitive stage of all. The later mustard gas treatments are those having the highest effect at this stage. They are therefore consistent in yielding the highest breakage frequency as well as the highest proportion of chromatid breaks.

\section{TABLE 5}

Coefficients of reunion of $B^{\prime}$ with one another and to give triradials $B^{\prime} B^{\prime \prime} R^{\prime}$ for all periods

\begin{tabular}{|c|c|c|c|c|}
\hline$B^{\prime}$ p. cell & $B^{\prime}$ & $B^{\prime} R^{\prime}$ & $B^{\prime} B^{\prime \prime} R^{\prime} \div 2$ & $\mathrm{ECR}^{\prime}$ \\
\hline $\begin{array}{c}1 \\
2 \\
3 \\
4 \\
5 \text {-10 }\end{array}$ & $\begin{array}{l}52 \\
76 \\
33 \\
28 \\
47\end{array}$ & $\begin{array}{l}\ldots \\
40 \\
17 \\
12 \\
20\end{array}$ & $\begin{array}{l}3.5 \\
4 \\
1 \\
1 \\
3.5\end{array}$ & $\begin{array}{r}+.07 \\
\cdot 52+.05 \\
\cdot 52+.03 \\
44+.04 \\
\cdot 42+.07\end{array}$ \\
\hline
\end{tabular}

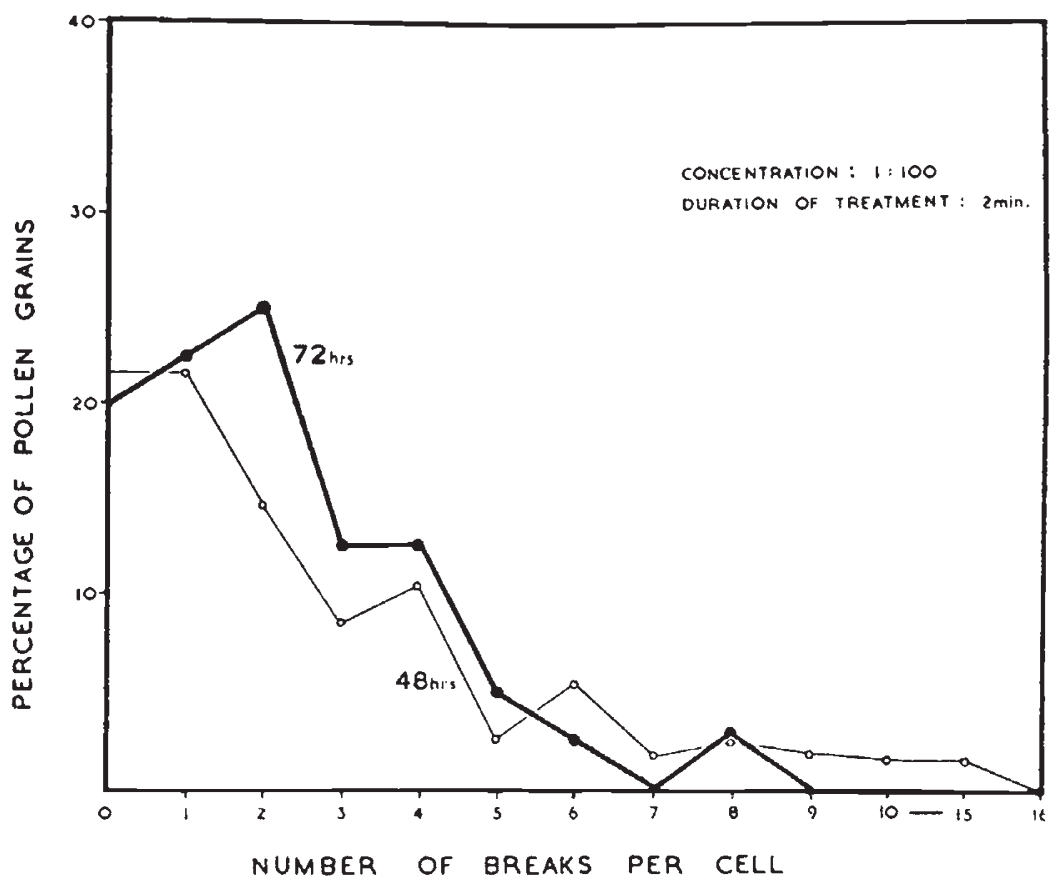

Frg. 14.-Frequencies of cells with different numbers of breaks $\left(B^{\prime}, B^{\prime \prime}\right.$ and minutes but not subminutes), 48 and 72 hours after treatment (not represented in a table). Cf. Darlington and La Cour (1945), graph $\mathrm{I} 3$.

Reunion $\left(\mathrm{R}^{\prime \prime}\right.$ and $\left.\mathrm{R}^{\prime}\right)$. The proportion of broken ends of chromosomes and chromatids which undergo reunion (the Empirical Coefficient of Reunion or ECR) is much lower than with high intensity $\mathrm{X}$-raying. It corresponds with the values obtained at low intensities (table 4 and Koller, 1946). 
The very low frequency of $R^{\prime \prime}$ as compared with $R^{\prime}$ is due to the lower frequency of $\mathbf{B}^{\prime \prime}$ than of $\mathbf{B}^{\prime}$, a frequency also which is spread over a longer time : to allow of reunion two breaks must be present in the same cell at the same time. This low $R^{\prime \prime}$ is another condition favouring the high proportion of triradials from $B^{\prime}-B^{\prime \prime}$ unions already discussed. These have been separately recorded (table 5 ). These

TABLE 6

Frequencies of cells with different numbers of chromatid breaks and reunions (excluding $B^{\prime \prime} R^{\prime}$ ) for all three periods, showing retention of excess even breaks by excess of paired reunion. Reproduced in the graph, fig. ${ }_{15}$. (Cf. table ${ }_{15} B$ and graph 14 in Darlington and La Cour, 1945)

\begin{tabular}{|c|c|c|c|c|c|c|c|c|c|c|c|}
\hline & \multicolumn{10}{c|}{ Numbers per cell } \\
\hline & 0 & $\mathrm{I}$ & 2 & 3 & 4 & 5 & 6 & 7 & 8,9 & 10 & $\mathrm{~T}$. \\
\hline $\mathbf{B}^{\prime}$ & 95 & 32 & 38 & $1 I$ & 7 & 2 & $\mathrm{I}$ & 3 & $\ldots$ & $\mathrm{I}$ & 190 \\
$\mathrm{R}^{\prime}$ & 50 & 12 & 24 & 5 & 4 & $\ldots$ & $\ldots$ & $\ldots$ & $\ldots$ & $\ldots$ & 95 \\
$\mathbf{B}^{\prime}-\mathbf{R}^{\prime}$ & $\ldots$ & 20 & 14 & 6 & 3 & 2 & $\mathrm{I}$ & 3 & $\ldots$ & 1 & 50 \\
\hline
\end{tabular}

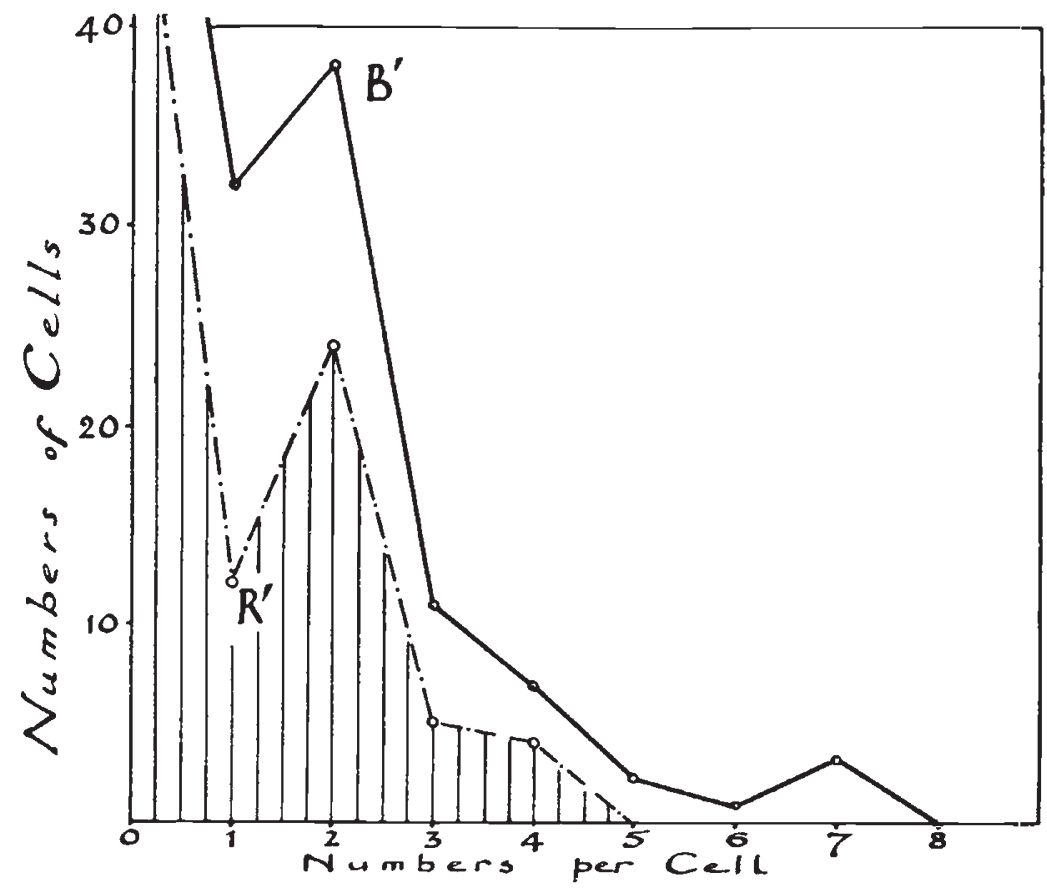

Fig. 15-Frequencies of cells with different numbers of $\mathbf{B}^{\prime}$ and $\mathbf{R}^{\prime}$ (from table 6i).

reunions are asymmetrical and therefore have a damping effect on the predominance of paired reunions and of the paired breaks which they preserve from restitution and consequent disappearance. The 
zigzag EGR' frequency curve with breaks per cell therefore disappears with mustard gas ( $c f$. Darlington and La Cour, 1945, graph 16). Nevertheless the excess of even numbers, so remarkable in the X-ray results, is still detectable in the mustard gas experiments. The excess disappears, as it should do, when $R^{\prime}$ is subtracted from $\mathrm{B}^{\prime}$ (table 6 and fig. I5).

Sister reunion (SR). The non-division of the end-gene is higher in the acentric than in the centric fragments produced by chromosome breakage $\left(\mathrm{B}^{\prime \prime}\right)$. For both classes it is highest in those cells having the lowest numbers of breaks (table 8 ).

Minutes $(\mathrm{m})$. The relative frequencies of minutes at different stages following X-ray treatment at a favourable temperature can be calculated from the frequencies of large fragments and of their reunions on the assumption that the two breaks responsible for them are independent of one another (Darlington and La Cour, 1945, table I I). The same formula applies satisfactorily to the mustard gas data in giving expectations at different periods relative to one another (with a maximum at 72 hours). But the frequencies of minutes relative to the large fragments are four times as high as with intense X-ray treatment. This is perhaps another symptom of the concentration effect since it is also found with low-intensity X-ray treatment.

\section{(iii) Quantitative : Meiosis}

In pollen mother cells of Tradescantia bracteata, the six bivalents are ring or rod-shaped, each having one or two chiasmata. The chiasma frequency is between $\mathrm{I} \cdot 6 \mathrm{O}$ and $\mathrm{I} \cdot 75$ per bivalent with very high terminalisation (table 7).

\section{TABLE 7}

Chiasma frequency in samples of 50 treated and untreated pollen mother cells of Tradescantia bracteata (300 potential bivalents)

\begin{tabular}{|c|c|c|c|c|c|c|}
\hline Concentration & Exposure & $\begin{array}{l}\text { Time after } \\
\text { treatment }\end{array}$ & $\begin{array}{l}\text { Total } \\
\text { Xta }\end{array}$ & $\underset{\text { Xta }}{\text { Terminal }}$ & $\underset{\text { per celI }}{\text { Xta }}$ & $\begin{array}{c}\text { Terminal } \\
\text { coefficient }\end{array}$ \\
\hline Control & \multicolumn{2}{|c|}{$\begin{array}{l}\text { P. C. Koller (1943) } \\
\text { L. F. La Cour (1946) }\end{array}$} & $\begin{array}{l}480 \\
526\end{array}$ & $\begin{array}{l}4^{64} \\
5^{20}\end{array}$ & $\begin{array}{l}x \cdot 60 \\
I \cdot 75\end{array}$ & $\begin{array}{l}0.96 \\
0.98\end{array}$ \\
\hline $\begin{array}{l}\text { Pure } \\
1: 100 \\
1: 100\end{array}$ & $\begin{array}{l}1 \text { min. } \\
5 \text { mins. } \\
5 \text { mins. }\end{array}$ & $\begin{array}{l}12 \mathrm{hrs} . \\
24 \mathrm{hrs} . \\
4^{8} \mathrm{hrs} .\end{array}$ & $\begin{array}{l}475 \\
561 \\
582\end{array}$ & $\begin{array}{l}471 \\
374 \\
231\end{array}$ & $\begin{array}{l}x \cdot 56 \\
x \cdot 87 \\
x \cdot 94\end{array}$ & $\begin{array}{l}0.99 \\
0.66 \\
0.39\end{array}$ \\
\hline
\end{tabular}

Chiasma frequencies were recorded in $5^{\circ}$ cells 12 hours after treatment with pure, and 24 and 48 hours after treatment with dilute, mustard gas. In the 12 hours' sample, the chiasma frequency was not significantly below normal. Evidently the chiasmata had been formed more than 12 hours before metaphase. Twenty-four hours and 48 hours after treatment with the weak mustard gas the number 
of chiasmata is raised. Ring-shaped bivalents become commoner and terminal localisation is reduced. In other words, more chiasmata are formed and further from the ends. Since pairing is supposed to begin at the ends in Tradescantia, this result would follow if the time limit to pairing were merely postponed (Darlington, r940). The reverse effect occurs in the procentrically localised pairing of Fritillaria at high temperatures: the time limit is advanced and localisation is increased (Barber, 1942).

An extension of the time available for the pairing of chromosomes would presumably arise from a delay in the accumulation of the proteins needed for their reproduction. It is therefore significant that Mather (1934) found an increased chiasma frequency, and La Cour (1946) widened distribution of localised chiasmata, following $\mathrm{X}$-raying.

\section{(6) CHEMICAL, RADIATION AND SPONTANEOUS EFFECTS}

The distinction between spontaneous and temperature-induced errors on the one hand, and chemical and radiation errors on the other, seems to be in the more specific timing of the former kind. They include every type of error induced by mustard gas or slow $\mathrm{X}$-rays save for misdivision and the formation of subminutes at mitosis ; and both of these may well be due to the concentration effect. Since in most spontaneous cases, however, as we saw, a specific error occurs by itself, owing to its being precisely timed, we should not expect concentration effects.

With breakage induced by X-rays or by mustard gas, on the other hand, we always have the whole series of nucleic acid and protein errors together. It is only by using low doses of either that some separation can be made between the primary and secondary effects. In short, the methods of breaking the chromosomes by chemical or irradiation treatment are, both of them, blunt instruments, have a less specific effect, and the chemical treatment a less precisely timed effect, than can be produced by the adjustment of abnormal environments and genotypes in "spontaneous" breakage.

The effects of mustard gas on the cell are revealed in the metaphases within 24 hours in two ways : (i) by a derangement of the nucleic acid metabolism, as shown by errors in the charging, reproduction and spiralisation of the chromosomes; and (ii) by a derangement of the protein organisation, as shown by the centromeres and the spindle. The centromere appears as specially sensitive both in these experiments and in those of Auerbach as suggested by mosaics (1946) and by delayed errors at the following meiosis (1947). These errors are associated with other mutations probably due to loss of a chromosome segment. The whole syndrome could be due to misdivision at the first mitosis in the egg which would lead to loss of the short arm of the $\mathrm{X}$. The breakage of the centromere, sometimes at prophase, sometimes at anaphase, provides the first experimental analogy with the 
spontaneous breakages at the centromere previously seen in Tradescantia and Tulipa.

Since the centromere anomalies are the first to appear they are probably the last to occur in the cycle, that is just before metaphase. The occurrence of errors in its development and its actual breakage under the influence of both radiation and chemical treatment at prophase, the very stage when the rest of the chromosome is immune to breakages, is evidence of its structure and development. At this stage the rest of the chromosome is taking up a charge of nucleic acid which is giving it a rigid spiral framework. The centromere, on the other hand, is losing what charge it had as it prepares to organise by direct action the protein arrangement of the spindle. The chromosome is taking up protective covering as its genes give up their activity. The centromere is losing its protective covering as its genes take up their activity. Hence their reciprocal change of sensitivity equally to chemical and to radiation attack (Darlington, 1947).

The centromere effect may well be characteristic of all radiation treatment of prophase, but where intense doses have to be delivered immediately before metaphase in the sensitive stage, centromere damage is bound to be smothered by the nucleic acid effect. Prolonged treatment with low intensity X-rays or with mustard gas avoids this confusion.

After 24 hours the effects of action on nucleic acid and on the centromere disappear and the specific effect on chromosome breakage is left. This transition is parallel with that between the primary and secondary effects of X-ray treatment. With low X-ray doses, the transition can be more easily followed than in the present mustard gas treatments, but the principles are evidently the same.

The breakage effects of mustard gas and low intensity X-ray treatment are parallel. They both differ from high intensity dosage owing to the cumulative action of the slow treatments whether with the radiation or the poison. This action makes itself felt in two ways :-

(i) There is a low-intensity effect shown by low reunion. This does not, however, account for the low frequency of interchanges found by Auerbach, for in any case there is no reunion at all in Drosophila sperm.

(ii) There is a concentration effect shown by the formation of subminutes as well as by the dispersed frequency distribution in cells (fig. I4). The later part of each treatment is acting on chromosomes in a substrate already altered by the earlier part. Sax has inferred (I 94I, I 942) that acentric fragments are less breakable than centrics under a second X-raying. It seems rather that the reverse is true, especially in view of the characteristically higher sister reunion of acentrics; but in any case the effects of a prolonged treatment are likely to 
depart from the randomness of a purely physical experiment indicated by intense treatments, or treatments of simpler systems such as viruses or Drosophila sperm.

Even more may be learnt about the conditions of breakage from the comparison of the frequencies of reunion. The mustard gas effects agree with the X-ray effects, and contradict the spontaneous effects with Tulipa fragrans, in regard to sister-reunion. They do so in two ways (table 8, fig. I6) :-

(i) They show a higher sister-reunion in acentrics. This is obviously because the loss of the centromere upsets the nucleic acid charging and leads to non-division of the broken end-gene. The spontaneous breakage goes clean contrary. There is lower sister-reunion in acentrics. The reversal means that these breaks themselves are derived from nucleic acid defects due in turn to errors of the centromere : its loss is therefore more of a help than a hindrance.

(ii) They show less end-gene defect in cells with more breaks. Noticing this correlation in our mustard gas data, we re-examined the X-ray data and found they agreed. The explanation (which is not important for our present purposes) is probably that the disadvantages of being broken, and also of having no centromere, are now shared amongst numerous ends. With spontaneous breakage, on the contrary, there is more end-gene defect in cells with more breaks shared amongst numerous ends. Again the spontaneous breakage goes clean contrary to the induced and for the same general reason: the greater damage is a symptom of greater error in the cell, error in the nucleic acid metabolism.

The centromere and nucleic acid errors which are induced by the $\mathrm{X}$-rays and mustard gas are induced with great rapidity and are invariable concomitants of the breakage although they may no longer be in evidence at the time when resting stage breaks reach metaphase. It is therefore of great importance to know that, while spontaneous breakage is dependent on these errors, induced breakage, of both types is independent of them. In other words, it is direct rather than indirect.

We now have to examine an assumption at the opposite extreme. It has been held that the radiation breakage of chromosomes arises from the direct, or almost direct, action of the ionising particles on the gene-string. Such a view could hardly be maintained for a chemical mutafacient. The close relationship between X-ray and mustard gas effects, therefore, makes it worth while to re-examine the direct ionisation theory. 
TABLE 8

Sister reunion related to breakage frequency in individual cells (cf. fig. 16)

(a) Following mustard gas treatment in the experiments recorded in table 4

\begin{tabular}{|c|c|c|c|c|c|c|}
\hline $\mathrm{B}^{\prime}$ p. cell & $\mathrm{B}^{\prime \prime}$ & $\mathrm{B}^{\prime \prime} \mathrm{R}^{\prime \prime}$ & $\mathrm{SRC}_{0}$ & $\mathrm{EC}: \mathrm{SRC}_{0}$ & $\mathrm{SRC}_{1}$ & EC : $\mathrm{SRC}_{\mathbf{1}}$ \\
\hline I & 46 & 46 & 26 & $\cdot 57$ & 13 & .28 \\
\hline 2 & 50 & 47 & 22 & $\cdot 47$ & 9 & $\cdot 19$ \\
\hline 3 & 45 & 40 & 19 & 47 & 10 & .25 \\
\hline $4-5$ & 54 & 53 & 22 & $4 I$ & I I & $\cdot 2 I$ \\
\hline $6-10$ & $3^{I}$ & 28 & 9 & 32 & 5 & $\cdot 18$ \\
\hline Total & 226 & 214 & $9^{8}$ & $(\cdot 40)$ & $4^{8}$ & $(\cdot 23)$ \\
\hline
\end{tabular}

(b) Following spontaneous breakage in two classes of cells with low and high breakage in Tulipa fragrans (Darlington and Upcott, 194I)

\begin{tabular}{|c|c|c|c|c|c|c|c|c|}
\hline Cells & $\mathrm{B}^{\prime \prime}$ & $\mathrm{B}^{\prime \prime}$ p. C. & $\mathrm{R}^{\prime \prime}$ & $\mathrm{B}^{\prime \prime}-\mathrm{R}^{\prime \prime}$ & $\mathrm{SRC}_{0}$ & $\mathrm{EC}: \mathrm{SRC}_{0}$ & $\mathrm{SRC}_{1}$ & $\mathrm{EC}: \mathrm{SRC}_{1}$ \\
\hline $\mathrm{II}$ & 49 & $4 \cdot 5$ & $2 \mathrm{I}$ & 28 & 3 & $\cdot 11$ & 4 & $\cdot 14$ \\
\hline 4 & 44 & ${ }^{1} \cdot \mathrm{O}$ & 14 & 30 & 8 & $\cdot 27$ & 14 & $\cdot 47$ \\
\hline
\end{tabular}

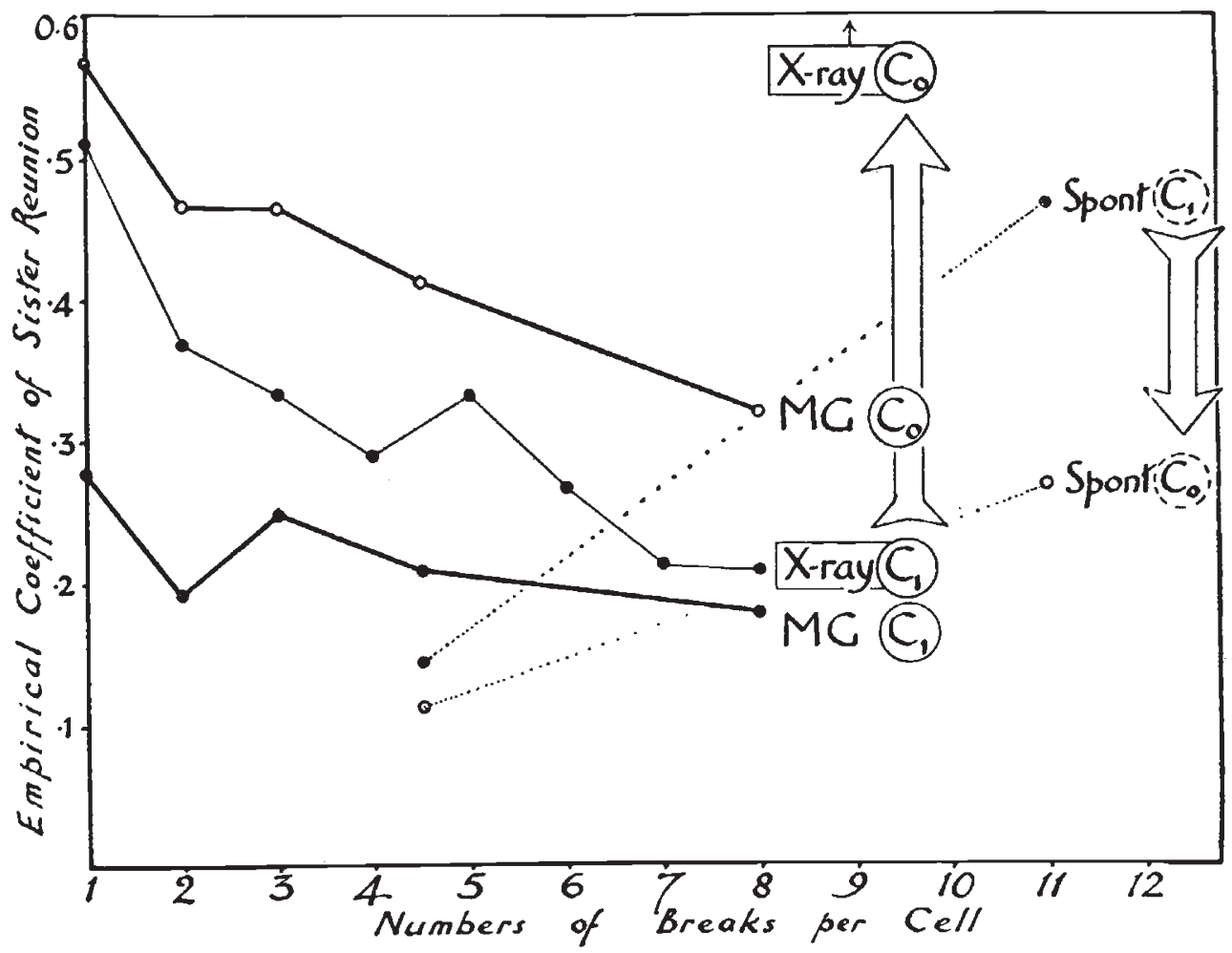

Fig, 16.-Graph showing the relationships of sister-reunion in pollen grains with high and low breakage in centric and in acentric fragments following :-

(i) Mustard gas treatment of Tradescantia bracteata. (Table $8(a)$.)

(ii) X-ray treatment of Trillium erectum (calculated from Darlington and La Cour (1945), table 16, p. 242.)

(iii) Spontaneous breakage in Tulipa fragrans. (Table $8(b)$. 


\section{(7) THE TARGET THEORY}

The view that a single ionisation within a given target will directly break a chromosome thread has been pursued farthest by Lea (1946). His argument rests on experiments of Sax, Catcheside, and other workers who have followed Sax's experimental methods and accepted his conclusions as a basis of further analysis. These experimental methods suffer from certain shortcomings of design and control. They depend on the assumption that not merely genes but also cells and organisms may be relied upon to react to treatment according to purely physical laws, to behave as targets when hit, and in short never to introduce any new variables into an experiment unless invited to do so.

This point of view was very advantageous when Jacques Loeb first revealed its possibilities, and it is still the foundation of a large part of what passes for experimental biology. But to-day it can lead the unwary physicist (or bio-physicist) into pitfalls. For example, temperature is of no consequence if the effect of ionisation is direct. For this reason, presumably, temperature control has been largely dispensed with in the experiments used by Lea as evidence. Only time has been controlled. But time means nothing for living organisms when the temperature is unknown.

By contrast with these fundamental fallacies of method, most of which have already been examined (Darlington and La Cour, I945; Koller, 1946), the fallacies of inference and classification derived by Lea from Sax are superficial. They are, however, destructive' of the analysis that rests on them. In the first place Sax (1939) showed, and the present experiments with the prolonged action of the poison entirely agree, that a spreading of irradiation with a low intensity over a long period resulted in fewer new unions, that is fewer rearrangements of chromosomes. Sax concluded that breaks " healed " quickly so that, unless two were formed in a cell at once, they could not reunite in a new way. Later Darlington and La Cour (1945) showed that healing did not occur in the resting nucleus, Muller (I940) and McClintock (1942) having already shown that it need not occur at all for many cell generations. Now, of course, we can go much further. The present experiments show, not only that breaks do not heal, but also that unbroken ends may unheal. Darlington and Upcott (194I) had also explained the reduction of reunion with prolonged treatments by assuming that new reunions had to compete with old reunions : restitution would forestall rearrangement unless more than one break happened at once. This assumption is vindicated by the increase of delayed reunion and the formation of triradials with the prolonged mustard gas treatment.

The assumption of competition, thus strengthened, enables us to rectify another early error. Already, in 1938, Sax, attempting to apply Mather's principle that B" are breaks of chromosomes before the 
split and $\mathrm{B}^{\prime}$ of chromatids after the split, had to explain why the same chromosome could show both $\mathrm{B}^{\prime \prime}$ and $\mathrm{B}^{\prime}$. He assumed that, in such cases, the $\mathrm{B}^{\prime \prime}$ were spurious and the result of two chromatids being broken by one " hit" (on the direct ionisation hypothesis). These "isochromatid breaks" have done service for many years and figure largely in Lea's work. But, unfortunately, no one who has recorded them has ventured to define where their spuriousness begins. As we see, in the present work, B's can, and do, unite with B"s to give triradials. Hence, as pointed out by Darlington and Upcott (1941), any B' can be the result of the reuniting of one chromatid of a $B^{\prime \prime}$ which leaves its sister unmended. And, further, it is the B's that are spurious and not the B"s ( $c f$. fig. 17).

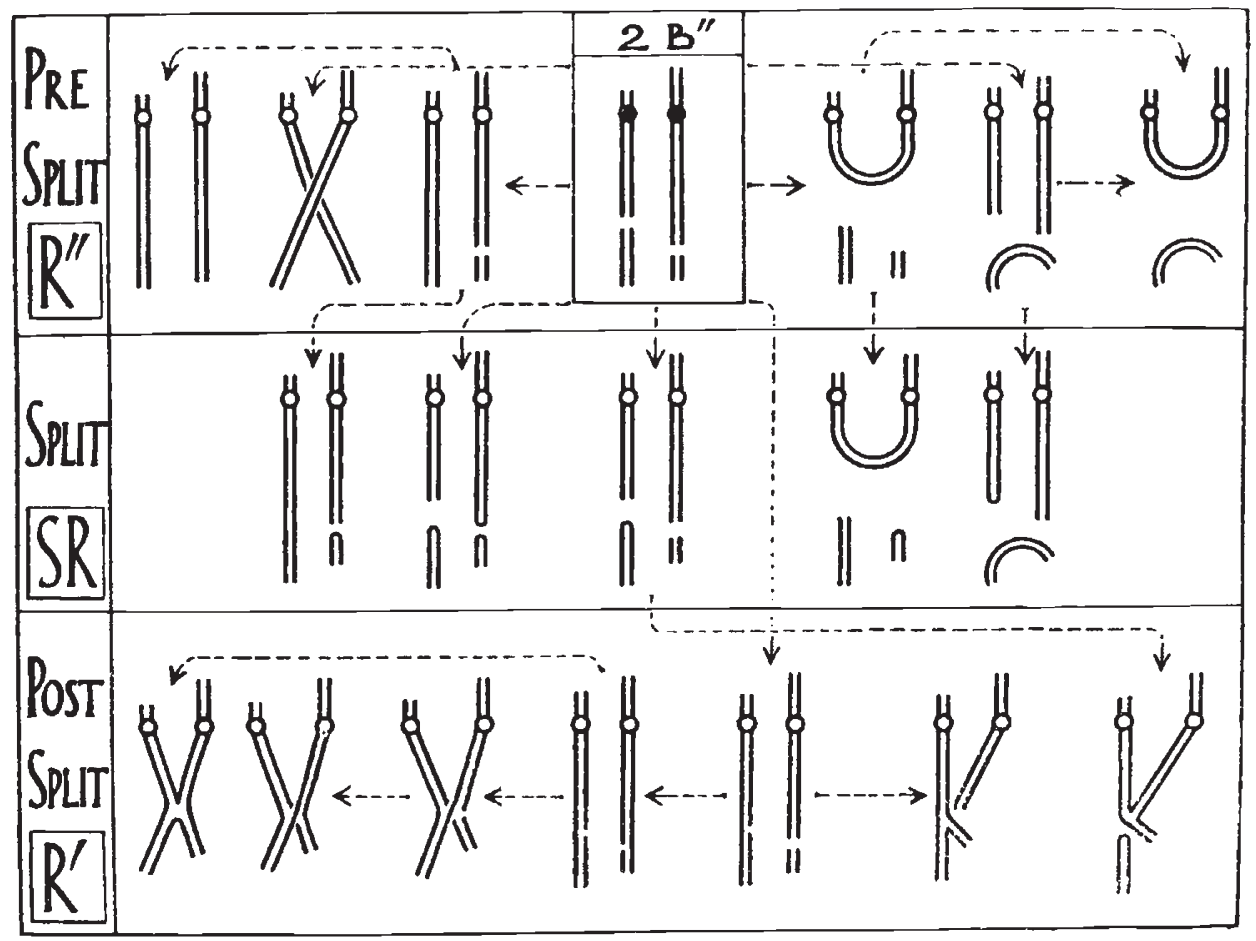

Fic. 17.-Some of the possible successions of changes that may follow two breaks $\left(\mathrm{B}^{\prime \prime}\right)$ in two chromosomes owing to restitution, $R^{\prime \prime}, S R$ and $R^{\prime}$. The pre-split stage is represented as split for ease of comparison. Each stage may be final and hence observable at the ensuing metaphase.

Note that $\mathrm{SR}$ is, so far as we know, independent on the two sides (centric and acentric) of a break.

What Sax's low intensity experiment proved, therefore, was not that broken chromosomes healed on an average within so many minutes, but that treated chromosomes broke on an average within so many minutes. This discovery, although it has hitherto been assumed by Lea, as well as by Sax, owing to the supposed indisput- 
ability of the direct ionisation hypothesis, is in fact most important and we can now build on it.

We now have four established positions. (I) The chemical and the radiation-induced breakage show the closest similarity and the reunions following them likewise. (2) Both of them happen only to chromosomes, or to parts of chromosomes, that have been stripped of nucleic acid, i.e. subject to the chemical surroundings of the genes at the time. (3) Both of them occur at the same time as injury to the nucleic acid metabolism, nevertheless both of them are independent of it. (4) The X-ray breakage happens within a few minutes of impact, the chemical breakage therefore presumably likewise. On these bases it is scarcely possible to doubt that both X-rays, as suggested by Muller (I940), and chemical breakage are immediately determined by chemical processes which in the X-ray case intervene between an ionisation and breakage. In the study of these chemical processes the work of Dale (1942), Mitchell (1943), Hevesy (1946), Latarjet (1946) and McAulay and Ford (1947) has been important and the mustard gas experiments may provide yet another means of attack.

\section{(8) SUMMARY}

I. Mustard gas applied to anthers as a dilute vapour for 2 minutes has a prolonged toxic action on the cell, and especially on the nucleus, like that of continuous low intensity radiation.

2. Its effects on mitosis and meiosis may be set down to injuries to both the nucleic acid metabolism and the protein structure. The first symptom is in a weakening of the centromere which later may break in the prophase or misdivide at anaphase. The second is in the stickiness of the nucleic acid charge on the chromosomes which affects their spiralisation and their reproduction. The third is in the breakage of the gene-string during the resting stage.

3. The breakage of the centromere at prophase of mitosis is due to its loss of nucleic acid protection at this stage when the rest of the chromosome is becoming protected. At the prophase of meiosis, however, the chromosomes are broken both before and (with different results) after pairing. These effects are all reproduced by X-raying but centromere breakage requires low intensities to be made visible.

4. Resting-stage breakage also corresponds with low intensity X-raying (i) in the low frequency of chromosome reunions $\left(\mathrm{R}^{\prime \prime}\right)$, (ii) in a concentration effect whereby minutes are broken to give subminutes and (iii) in a high frequency of triradials formed by the delayed union of chromosome breaks (and even of unbroken ends) with chromatid breaks.

5. These observations confirm the previous conclusions (i) that breaks do not heal in the resting nucleus (ii) that the intensity effect is due to competition for reunion and proves only that breakage is immediate, (iii) that apparent chromatid breaks can be derived from 
chromosome breaks by delayed reunion and (iv) that "isochromatid breaks" are fictitious.

6. Mustard gas and X-ray breaks differ from spontaneous breaks in the higher frequency of sister-reunion amongst acentrics. They also differ in having a lower frequency of sister-reunion in cells with more breaks. Both types of induced breakage are therefore independent of the simultaneous injury to the nucleic acid system on which spontaneous breakage is dependent.

7. The close similarity of chemical and physical breakage, and of their results, favours an indirect rather than a direct action of the ionising radiations on cells with a differentiation of nucleus and cytoplasm. Both these types of induced breakage are more complex in their conditions than spontaneous breakage.

AUERBACH, C. I943.

\section{REFERENCES}

D. melanogaster : New mutants. Chemically induced mutations and rearrangements. Dros. Inform. Service, No. $17,48-50$.

AUERBAGH, C. 1945 .

The problem of chromosome rearrangements in somatic cells of $D$. melanogaster.

P.R.S. Edin., B, 62, 120-127.

AUERBACH, c. I 946.

Chemically induced mosaicism in $D$. melanogaster.

P.R.S. Edin., B, 62, 2 I I-222.

AUERBAGH, c. 1947 .

Abnormal segregation after chemical treatment of Drosophila. Genetics, 32, 3-8.

AUERBACH, G., et al. 1943 .

Ministry Supply Report.

AUERBAGH, C., and RoBSON, J. M. I944.

Mutation chemically induced. Product of mutations by allyl isothio-cyanite. Nature (Lond.), r54, 81.

AUERBACH, G., RobSON, J. M., and GARR, J. G. 1947.

The chemical production of mutations.

Science, ro5, 243-247.

BARBER, H. N. 1942 .

The experimental control of chromosome pairing in Fritillaria.

7. Genet., 43, 359-374.

BEADLE, G. W. $193^{2}$.

A gene for sticky chromosomes in Zea mays.

Z.I.A.V., 63, 195-2 I 7 .

BERENBLUM, I., et al. 1936 .

Tumour metabolism in the presence of anti-carcinogenic substances.

Biochem. F., 30, 709-715.

GASHMORE, A. E., and $\mathrm{M}^{\mathrm{C}} \mathrm{COMBIE,} \mathrm{H.} \mathrm{I923.}$

The interaction of $\beta, \beta^{\prime}$-dichlorodiethyl sulphide, sulphoxide and sulphur with glycine ester and with potassium phthalamide.

7. Chem. Soc., 2884-289o. 
Plates I and II.-Microphotographs of Tradescantia bracteata treated 12-72 hours earlier with mustard gas. $\times 2220$.

Plate I. Pollen mother cells

Figs. I and 2.-Laggards. ( $1: 10 / 2 \mathrm{~min} . / \mathrm{r} 2 \mathrm{hrs}$.)

Fig. 3.-Misdivision of centromere in a univalent with irregular nucleic acid starvation. ( 1 : $100 / 2 \mathrm{~min} . / \mathrm{s} 2 \mathrm{hrs}$.)
FIg. 4.-Fragmentation, non-spiralisation and starvation at metaphase. ( $1: 100 / 2$ $\min . / 48 \mathrm{hrs}$.). $C f$. Text fig. I 1 .

FIG. 6.-Acentric fragments forming a secondary plate where the cell wall should be laid down. (I : 100/2 $\mathrm{min}$.) 72 hrs.) 


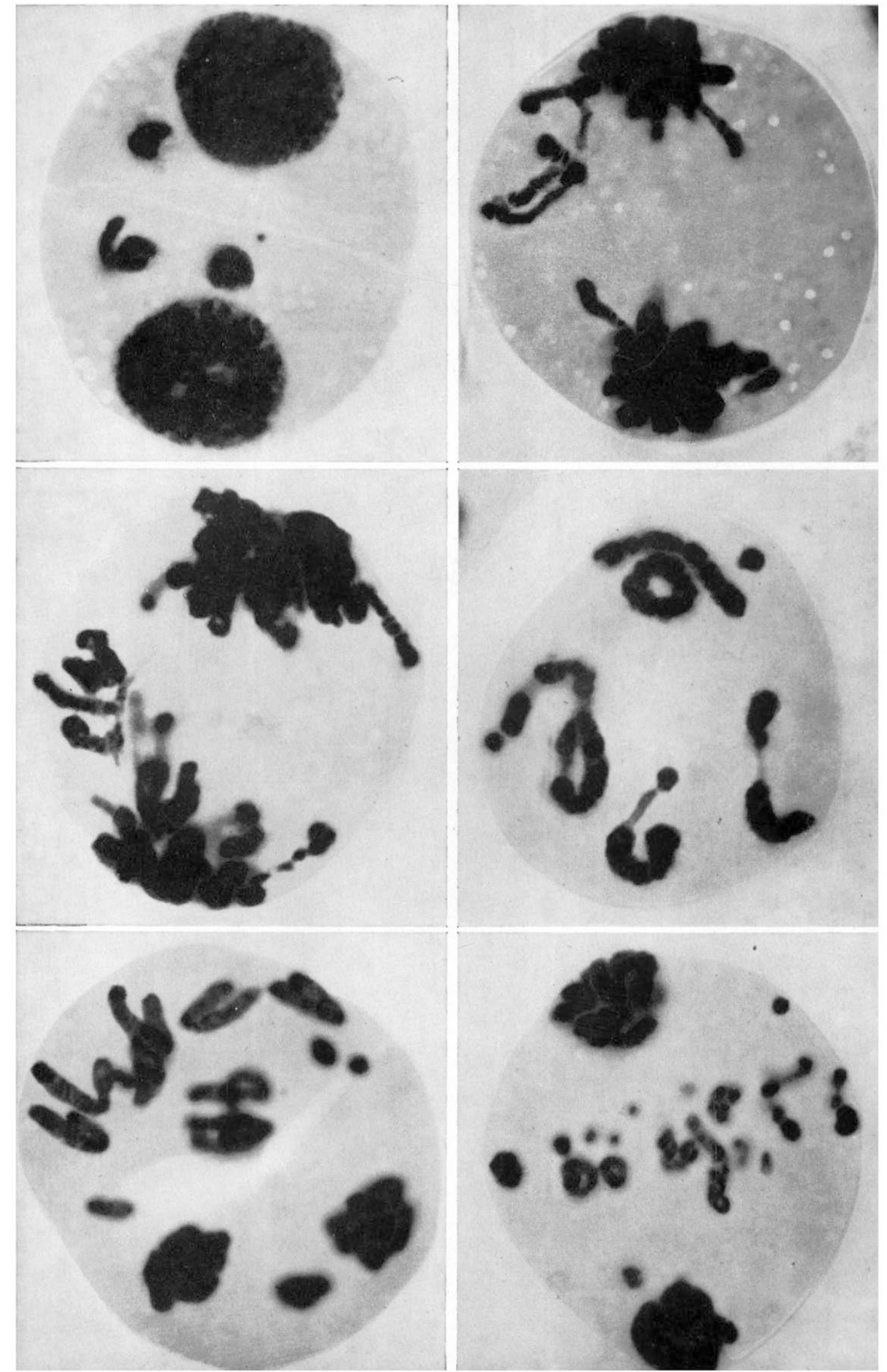


FIG. 7.-Nuclear clotting. (I : $10 / 4 \mathrm{~min}$./ 24 hrs.)

FIG. 9.-Centric breaks and reunion with some starvation. (I : $100 / 2 \mathrm{~min}$./ $4^{8}$ hrs.)
FIG. 8.-Nuclear shattering with some nucleic acid starvation. (Pure mustard gas/2 min./ 24 hrs.)
FIG. 10.-Centric breaks and reunions, with $\mathrm{B}^{\prime}, \mathrm{B}^{\prime \prime}, \mathrm{SRC}_{0}$ and $\mathrm{SRC}_{1}$. ( $\mathrm{I}: \mathrm{i} 00 / 2 \mathrm{~min} . /$ $72 \mathrm{hrs}$.)
FIG. I1.-Prophase reunion and $B^{\prime \prime}$; irregular spiralisation. (I : $100 / 2 \mathrm{~min}$./ $4^{8} \mathrm{hrs}$.)
FIs. I 2.- Interchanges $\left(\mathrm{B}^{\prime} \mathrm{R}^{\prime}\right) . \quad(\mathrm{I}: 100 / 2$ min. $/ 48$ hrs.) 

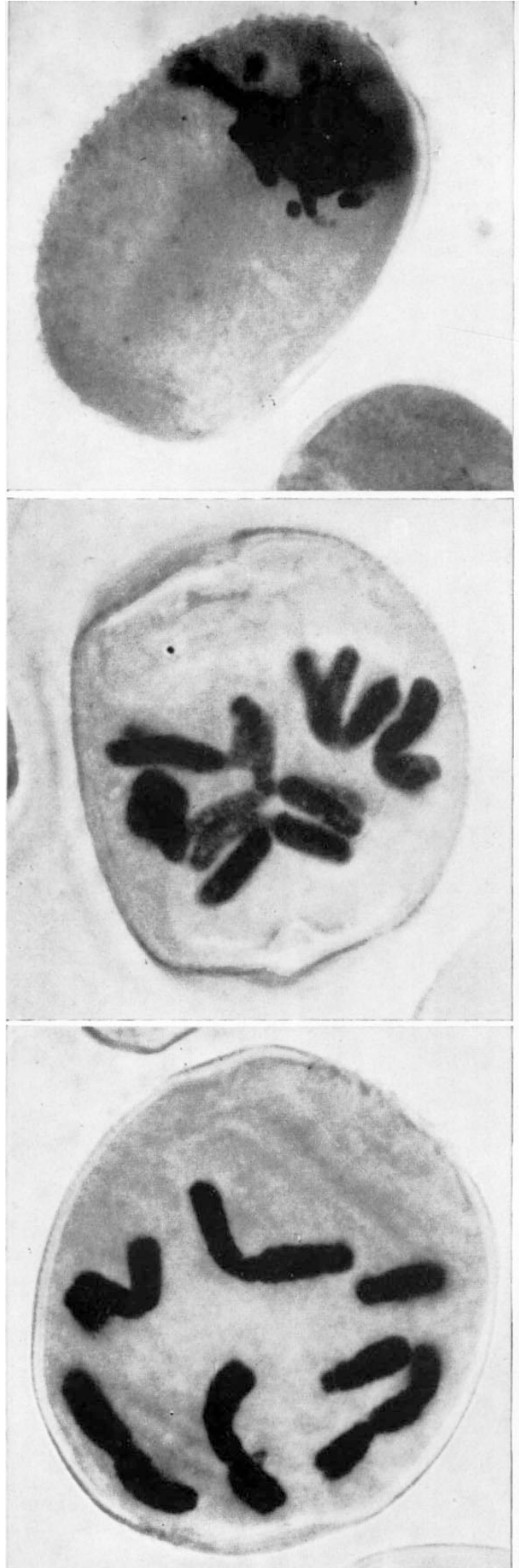
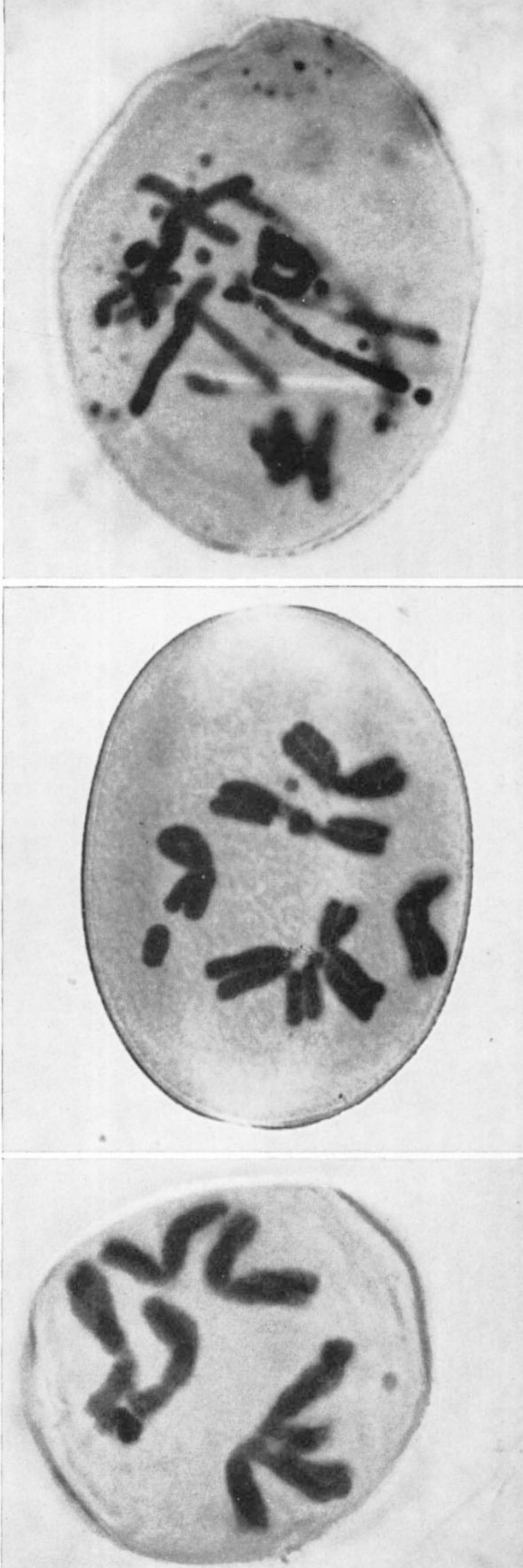
CHevais, J., and thomas, J. A. I 943 .

Variation du taux de mutations provoquées par l'aminophénylsulphamide chez la

Drosophile suivant le délai compris entre le traitement du male et le croisement. C.R. Soc. Biol., 137, 187-189.

DALE, W. M. 1942.

The effect of X-rays on the conjugated protein $d$-amino-acid oxidase.

Biochem. 7., 36, 80-85.

DARLINGTON, C. D. 1937.

Recent Advances in Cytology. 2nd ed. London.

DARLington, C. D. 1939 .

Misdivision and the genetics of the centromere.

7. Genet., 37, 341-364.

DARLINGTON, C. D. 1940 .

The prime variables of meiosis.

Biol. Rev., 15, 307-322.

DARLINGTON, C. D. 1942 .

Chromosome chemistry and gene action.

Nature (Lond.), 149, 66-69.

DARLINGTON, C. D. 1944 .

Heredity, development and infection.

Nature (Lond.), 154, 164-169.

DARLINGTON, C. D. 1947.

Nucleic acid and the chromosomes.

Symp. Soc. exp. Biol. I. Nucleic Acid, 252-269.

DARLINGTON, C. D., and LA COUR, L. F. 1945.

Chromosome breakage and the nucleic acid cycle.

7. Genet., 46, 180-267.

DARLiNGTON, C. D., and LA COUR, L. F. 1947.

The Handling of Chromosomes. 2nd ed. London.

DARLington, C. D., and UPCOTT, M. B. I $194 \mathrm{I}$.

Spontaneous chromosome change. F. Genet., 4I, 297-338.

GILman, A., and Philips, F. s. 1946.

The biological actions and therapeutic applications of the $\beta$-chloroethyl amines and sulphides.

Science, 103, 409-415.

HADORN, E., and NIGGLI, H. I946.

Mutations in Drosophila after chemical treatment of gonads in vitro.

Nature (Lond.), 157, 162-163.

HADDOW, A. I 944 .

Transformation of cells and viruses.

Nature (Lond.), 154, 194-199.

HARTWELL, J. L. 1946.

Reactions of bis (2-chloroethyl) sulphide and some of its derivatives with proteins and amino acids.

7. Nat. Cancer Inst., 6, 319-324.

HeVESX, G. 1946 .

Effect of X-rays on the rate of turnover of phosphatides.

Nature (Lond.), ${ }_{5} 8,268$. 
HOLLAENDER, A. I 946 .

Effects of ultraviolet radiation.

Ann. Rev. Physiol., 8, I-16.

HOROWITZ, N. H., et al. $\quad$ I 946 .

Mustard gas mutations in Neurospora.

Science, 104, 233-234.

KOLLER, P. C. $\quad$ I938.

Asynapsis in Pisum sativum.

7. Genet., 36, 275-306.

KOLLER, P. C. I 943 .

The effects of radiation on pollen grain development, differentiation and germination. P.R.S. Edin., B, 6r, 398-429.

KOLLER, P. C. $\quad 1946$.

The response of Tradescantia pollen grains to radiation at different dosage-rates.

Brit. F. Radiol., 19, 393-404.

KOLLER, P. C. I947a.

Experimental modification of nucleic acid systems in the cell.

Symp. Soc. exp. Biol. I. Nucleic Acid, 270-29o.

KOLLER, P. C. I947b.

Abnormal mitosis in tumours.

Brit. 7. Cancer $1,3^{8-47}$.

LA COUR, L. F. $\quad$ I 946.

Fohn Innes Hort. Inst. 36 th Ann. Report, 1945.

LATARJET, R. I 946 .

L'effet biologique primaire des radiations et la structure des microorganismes.

Rev. Canad. de Biologie, 5, 9־47.

LEA, D. E. I $\quad$ 946 .

Actions of Radiations on Living Cells. Cambridge.

MACKENZIE, K., and MULLER, H. J. I940.

Mutation effects of ultra-violet light in Drosophila.

P.R.S., B, 129, $49^{\mathrm{I}-5}{ }^{\mathrm{I}} 7$.

${ }_{\mathrm{M}} \mathrm{C}_{\mathrm{AULAY}}$, A. L., and FORD, J. M. 1947.

Saltant production in the fungus Chotomium globosum by ultra-violet light, etc.

Heredity, $I, 247-257$.

$\mathrm{M}^{\mathrm{C}}$ CLINTOCK, B. $194^{2}$.

The fusion of broken ends of chromosomes following nuclear fusion.

P.N.A.S., $28,45^{8-463}$.

MATHER, K. I 934 .

The behaviour of meiotic chromosomes after X-irradiation.

Hereditas, 19, 303-322.

MITCHELL, J. S. I 943 .

Metabolic effects of therapeutic doses of $\mathrm{X}$ and gamma radiations.

Brit. F. Radiol., 16 , 339-343.

MULLER, H. J. I 940 .

An analysis of the process of structural change in chromosomes of Drosophila.

7. Genet., 40 , I-66. 
OEHLKERS, F. I 943 .

Die Auslösung von Chromosomen-mutationen in der Meiosis durch Einwirkung von Chemikalien.

Z.I.A.V., 8I, 31 3-34I.

VAN POTTER, R. 1945 .

The genetic aspects of the enzyme-virus theory of cancer.

Science, ror, 6o9-6 ro.

SAX, K. 1938.

Chromosome aberrations induced by X-rays.

Genetics, 23, 494-516.

SAX, K. 1939 .

The time factor in X-ray production of chromosome aberrations.

P.N.A.S., 25, 225-233.

SAX, K. I 94 I .

Types and frequencies of chromosomal aberrations induced by $\mathrm{X}$-rays.

Cold Spr. Harb. Symp., 9, 93-1 ०3.

SAX, K. 1942.

The mechanisms of X-ray effects on cells.

7. gen. Physiol., 25, 533-537.

SLIZYNSKI, B. M. I943.

D. melanogaster. Stock Lists. British Isles.

Dros. Inform. Service, No. I $7,43$.

STADLER, L. J. I94I.

The comparison of ultra-violet and X-ray effects on mutation.

Cold Spr. Harb. Symp., 9, I68-1 77.

STRONG, L. C. 1945 .

Germinal mutations and other sudden biological changes following the subcutaneous injection of methylcholanthrene.

P.N.A.S., 31, 290-293.

STUBBE, H. I940.

Neue Forschungen zur experimentellen Erzeugung von Mutationen.

Biol. Zbl., 6o, I 1 3-129.

woods, w. M., and DuBuY, H. G. 1945 .

Cytoplasmic diseases and cancer.

Science, 102, 591-593. 